\title{
Narrativas fotográficas sobre a cidade ${ }^{1}$
}

Zita Rosane Possamai

UFRGS

RESUMO

Este artigo traça relações entre fotografia e narrativa, fotografia e coleção. Consideram-se os álbuns fotográficos enquanto coleção que apresenta uma determinada narrativa configurada pelo ordenamento das imagens fotográficas no seu interior. A partir da leitura visual de um álbum de vistas da cidade de Porto Alegre, propõe-se uma metodologia de abordagem dos álbuns e imagens fotográficas que busca tecer uma narrativa ensejando sentidos precisos, procurando dar a ver uma cidade de feições modernas.

Palavras-chave: Fotografia; cidade; coleção; imaginário; modernidade.

\section{ABSTRACT}

This article establishes relations between photography and narrative, photography and collection. It focuses photographic albums as collections that present a certain narrative configured by the sequential arrangement of the images in their interior. From the images of an album of Porto Alegre cityscapes, it proposes a methodology to approach albums and photographic images in order to build a narrative that creates meaning by trying to unveil a city of modern features.

Keywords: Photography; city; collection; imaginary; modernity.

O álbum fotográfico ao selecionar e reunir determinadas imagens fotográficas remete à coleção e à narrativa, ambas ligadas à memória.

De todo o repertório de imagens criado pelo homem moderno, sem dúvida, a fotografia é a que mais propicia a prática do colecionismo. A imagem fotográfica pode ser copiada em suporte de custo relativamente baixo e que torna acessível de forma imediata o objeto de coleção, a imagem, diferentemente de um vídeo ou mesmo da televisão, que requerem aparelhagem para se obter acesso. Além disso, o próprio exercício fotográfico, ao fazer surgir uma quantidade inesgotável de imagens acaba por criar coleções. ${ }^{2}$ Por essas características, desde o seu surgimento, a fotografia engendrou coleções, se- 
jam aquelas sobre acontecimentos restritos a um pequeno grupo de pessoas, como são os retratos de família, sejam aquelas sobre mundos distantes, como são as fotografias de viagens e as vistas urbanas.

As imagens fotográficas, assim, vieram a compor uma prática mais remota no tempo e que se refere à atividade humana de colecionar e, conseqüentemente, classificar e catalogar, como forma de conhecer o mundo. Graças aos gabinetes de curiosidades ou das câmaras das maravilhas dos séculos XV e XVI, fragmentos do Novo Mundo eram colocados à disposição de estudiosos como forma de apreensão não apenas de territórios desconhecidos, mas também do 'outro. ${ }^{3}$ Era assim que nas coleções científicas surgiam lado a lado pedras e gemas preciosas, exemplares da fauna e da flora, fragmentos de corpos de membros de tribos nunca antes vistas. Colecionar, catalogar e classificar eram práticas concebidas como forma de aproximar o mundo e as coisas até então desconhecidas pelo homem europeu. As coleções eram, dessa forma, o meio através do qual adquiria visibilidade um mundo invisível situado em terras exóticas e longínquas. Nessa perspectiva, quando de sua invenção, a fotografia ao ser percebida como registro fidedigno da realidade cumpriu muito adequadamente uma das funções mais importantes da coleção, ou seja, tornar visível aquilo que era, até então, invisível. ${ }^{4}$ No entanto, no caso das fotografias, perdeu-se a noção de que elas atuavam como semióferos, ${ }^{5}$ ou seja, objetos que possuíam determinado significado, o de representar mundos distantes. As fotografias foram tidas como pedaços da realidade. Colecioná-las, nesse sentido, significava colecionar também esses pedaços de mundo. ${ }^{6}$

Desde então, a prática do colecionismo de fotografias tornou-se crescente, acompanhando o próprio fazer fotográfico e atingindo, na era contemporânea, uma dimensão espantosa. Preocupada com isso é que Susan Sontag perguntava-se até que ponto pode-se atingir o conhecimento se as imagens, notadamente as fotográficas, interpõem-se entre o homem e o mundo, determinando, sobremaneira, a forma de conceber os processos e os fenômenos que o cercam. ${ }^{7}$ Se não se pode alcançar o conhecimento do mundo, a fotografia permite a coleção do objeto fotografado e, nesse sentido, colecionar fotografias significa poder colecionar o mundo, as coisas e as pessoas.

O álbum é, sem dúvida, a feição mais remota que adquiriu a coleção de imagens fotográficas. Nele, como em qualquer coleção, é estabelecida uma escolha arbitrada pelo colecionador. Assim, o álbum fotográfico configura uma seleção de determinadas imagens, entre tantas outras vistas por aquele que o elaborou, e, dessa forma, implica sempre determinado olhar. ${ }^{8}$ Esse viés não é 
ingênuo ou aleatório, pois segue critérios, idéias ou intenções, pautadas, por sua vez, pelo imaginário ${ }^{9}$ social da época em que foi produzido. Assim como a imagem fotográfica é elaborada pelo seu autor, o fotógrafo, de acordo com sua visão de mundo e conforme as concepções de toda ordem que o norteiam, da mesma maneira opera-se com a reunião de imagens selecionadas pelo autor do álbum. Deve-se ressaltar que o autor, nesse caso, e diferentemente do ato fotográfico que é executado única e exclusivamente apenas por um indivíduo, pode ser uma ou várias pessoas, uma instituição, um grupo, uma família.

Assim, o imaginário social interfere tanto na criação das imagens fotográficas, como na concepção da coleção que resultou no álbum fotográfico. No outro extremo, o da recepção, o álbum e as imagens nele contidas contribuem para a construção e veiculação de um determinado imaginário, neste caso, lançando mão da visualidade como elemento central.

Ademais, a fotografia opera de forma fragmentária e descontínua. A coleção, em especial o álbum fotográfico, pretende restituir a continuidade perdida na imagem fotográfica isolada. No caso do álbum de vistas urbanas, essa intencionalidade é ainda mais flagrante pela impossibilidade de ser alcançada em uma única representação fotográfica a dimensão colossal do espaço urbano. Assim, as imagens fotográficas ao elaborarem uma representação reduzida do gigantismo urbano, e ao estarem dispostas em um álbum, realçam essa idéia de continuidade, jogando com a ilusão de dar a ver a cidade em sua totalidade e em sua unidade espacial, inexoravelmente rompida pelo ato fotográfico.

Dessa maneira, elaborado a partir de fragmentos, tentando construir um mosaico da cidade consoante um imaginário específico, o álbum de vistas urbanas tenta alcançar uma continuidade fictícia. Essa continuidade, por seu turno, ganha sentido ao recorrer-se à construção narrativa e ao ter como lócus privilegiado de tessitura o espaço urbano, elemento visual preponderante na imagem fotográfica. Assim, conforme Jacques Aumont, tem-se a partir da imagem dois níveis de narratividade: aquele que se inscreve na imagem única, processo codificado em uma cena, e aquele que se situa na ordenação seqüencial das imagens fotográficas no interior do álbum fotográfico. ${ }^{10}$

Conforme Walter Benjamin, ${ }^{11}$ o declínio da narrativa é componente distintivo da experiência da modernidade. Na cidade moderna, com seu ritmo e velocidade vertiginosos, a troca de experiências interpessoais que propiciava a construção narrativa entra em declínio, dando lugar a outras formas de transmissão de informações. Na metrópole desaparecem também os grandes narradores depositários das vivências do grupo. Esses ancoravam seus relatos 
nas reminiscências, tornando o transcurso do tempo parte constitutiva do presente. Os guardiões da memória e da tradição, homens-memória, ${ }^{12}$ não apenas multiplicavam o conhecimento, transmitindo-o de geração em geração, como eram responsáveis pelo fortalecimento dos laços com um passado comum ligado a lugares e práticas tradicionais que contribuíam para a manutenção da coesão social do grupo.

A modernidade assistiu ao desaparecimento desses antigos laços com lugares e com práticas cuja significação era dada através das narrativas. Nesse contexto, continuando no raciocínio de Benjamin, ${ }^{13}$ o declínio da narrativa ensejou novas formas de comunicação, como a imprensa, que passou a substituir o antigo papel dos homens-memória. As imagens visuais, em especial as fotografias, também se revelaram como forma de dar a ver o mundo e as coisas, na perspectiva da plausibilidade exigida pela informação. ${ }^{14} \mathrm{~A}$ imagem fotográfica, nesse sentido, passou a ser considerada, na modernidade, um suporte por excelência da informação confiável a ser transmitida ao receptor, transformando-o de ouvinte/interlocutor em leitor visual. A imagem fotográfica, pelas características técnicas do fazer fotográfico, supostamente viria a fornecer um registro fiel dos acontecimentos, enquanto a narrativa abriria espaço para a interpretação, pretensamente banida das novas formas tecnológicas de representação da realidade. No entanto, conforme Flusser,

A aparente objetividade das imagens técnicas é ilusória, pois na realidade são tão simbólicas quanto o são todas as imagens. Devem ser decifradas por quem deseja captar-lhes o significado. Com efeito, são elas símbolos extremamente abstratos: codificam textos em imagens, são metacódigos de textos. A imaginação, à qual devem sua origem, é capacidade de codificar textos em imagens. Decifrá-las é reconstituir os textos que tais imagens significam... ${ }^{15}$

Dessa forma, as imagens fotográficas que, no contexto moderno, paulatinamente passam a substituir a narrativa tradicional, pouco ou nada dizem sem o recurso à narrativa. Como qualquer imagem, a fotografia transforma processos em cenas. ${ }^{16} \mathrm{Um}$ fragmento congelado no tempo que pretende tornar a realidade inteligível ao observador, mas que por sua forma de representação acaba por dificultar a compreensão desta. Assim, para decifrar as imagens fotográficas é necessário recorrer ao texto, caminho a percorrer a fim de ler o texto visual. É como se no contexto da cidade moderna e com o declínio da narrativa a imagem, em especial a fotográfica reunida no álbum, tentasse suprir o leitor de informações sobre a cidade. Porém, dessa forma, essa cida- 
de é ininteligível, nada mais sendo que fragmentos visuais sem significação. A objetividade intencionada pela apresentação exclusiva das imagens fotográficas se esvai quando o leitor visual necessita não apenas recorrer ao texto que a acompanha, no caso das legendas, mas também tecer uma narrativa que faça falar os elementos visuais e materiais do urbano representados como códigos configuradores da imagem fotográfica.

Ademais, o homem moderno, ao pensar distanciar-se das formas tradicionais de construção narrativa que tinham na memória ponto fundamental de apoio e de transmissão de vivências, atribui às imagens fotográficas, por sua peculiar pretensão à objetividade, a faculdade de reter o transcurso do tempo, congelando em imagens cenas urbanas a serem concebidas como pedaços da realidade presente ou passada. Embora não seja intenção explícita do fotógrafo ao clicar sua máquina elaborar um registro do seu tempo, inevitavelmente, ao serem preservadas, suas imagens tomarão lugar na elaboração da memória dos temas fotografados. Ao lado de outras formas de recuperação do passado, seja este próximo ou distante, as imagens fotográficas condicionam com grande intensidade a memória dos fenômenos pretéritos, por constituírem seu registro visual. A fotografia, assim concebida e utilizada, opera na construção de memórias na modernidade, substituindo formas convencionais que se ancoravam nas trocas de experiências interpessoais. Sendo seletiva, tal como a memória, opera com a trama do lembrar e do esquecer. Ao jogar o enquadramento sobre um pedaço do real, o que fica no interior deste é tido como memória, confundindo-se com o próprio passado, enquanto o que ficou de fora poderia ser concebido como o esquecimento e, por isso, não mais levado em conta.

Da mesma maneira ocorre com as vistas urbanas, largamente concebidas como a memória urbana resgatada pela fotografia. Memória em fragmentos, reminiscências dispersas, lembranças em frangalhos que obedecem tãosomente ao olhar daquele que esteve por trás da objetiva. Permanecem apenas como restos que, por algum descuido, não sumiram na poeira do tempo. $\mathrm{O}$ álbum de vistas urbanas, ao reunir esses fragmentos segundo uma ordenação lógica concebida pelo seu autor, funciona, assim, como coleção desses restos da cidade, elaborada para permanecer como memória de um tempo preciso que lançou sua marca no espaço ali presente em imagem.

Se o álbum, no entanto, permanecer fechado, sendo corroído pelo tempo implacável, nada dirá e, provavelmente, não atuará na memória do urbano presente nas suas imagens fotográficas. Ao ser folheado, no entanto, inevitavelmente uma narrativa será construída por seu leitor visual, surgirá uma 
trama que, por sua vez, se imbricará na narrativa elaborada por seu autor/ colecionador de imagens fotográficas. A partir daí estará construindo a memória e o esquecimento desse urbano, jogando com a visibilidade e invisibilidade dos traços da cidade.

Assim sendo, para proceder à análise das imagens fotográficas e dos álbuns - editados em determinado tempo e espaço e marcados por sua autoria enquanto coleção e enquanto construção narrativa que se faz memória e se faz esquecimento - considerei imprescindível assinalar o lugar do leitor visual. Não sendo meu objetivo analisar a recepção das imagens no contexto estudado, o lugar de leitor visual é assumido, neste texto, pela pesquisadora que tenta decifrar a narrativa construída pelo leitor visual/colecionador/editor do álbum, considerado também produtor visual.

A figura do flâneur $^{17}$ contribuiu, nessa direção, para uma aproximação dos álbuns fotográficos e da cidade ali representada. O flâneur, segundo Benjamin, ${ }^{18}$ é aquele que perambula pela cidade, detendo-se nos seus mais recônditos detalhes. Ele vagueia ociosamente pelo espaço da cidade moderna, não abdicando de sua subjetividade e, muitas vezes, colocando-se na contramão da aceleração do movimento urbano. O flâneur, assim, incorpora no seu caminhar através das ruas e calçadas a tessitura de uma narrativa, na qual incorpora suas interpretações pessoais desse vagar.

Dessa forma, proponho-me a percorrer os álbuns fotográficos de Porto Alegre tal qual o flâneur o faria pelo espaço urbano. Certamente, de todos os sentidos a visão será aquele preponderante, ao passo que na cidade cheiros e ruídos estariam à disposição da subjetividade do caminhante. Esse foco metodológico, porém, aponta para a análise da imagem visual que não prescinde da subjetividade do leitor visual na sua interpretação, estando esta condicionada aos mecanismos estéticos, culturais ou ideológicos da recepção das imagens.

Como o flâneur vagueia pelas ruas da cidade, o leitor visual necessita vagar seu olhar pelas páginas visuais dos álbuns fotográficos na busca de uma narrativa que torne plena de significação a imagem urbana ali construída. Para dar sentido a esse conjunto de imagens faz-se necessário, assim, tentar reconstituir o seu texto subjacente, o qual obedece a uma ordenação precisa pautada pela reunião e disposição das fotografias nos álbuns. Nesse sentido, a partir do álbum fotográfico, seus editores constroem uma narrativa sobre a cidade. Com o álbum procedem à escritura de um texto a partir de textos que tomaram a forma de imagens. A partir dessas considerações, passo a seguir a interpretar Porto Alegre Álbum, editado em 1931. 


\section{O OLHAR DETIDO}

Meu olhar ultrapassa a capa e encontra o texto do editor, ele também um leitor visual da Porto Alegre de sua época. Nas suas palavras, "Folheando esta larga reportagem fotográfica, o leitor se convencera de que Porto Alegre é uma cidade moderna, higiênica e de encantadora apresentação panorâmica...." ${ }^{19}$

Como flâneur deixo-me inebriar por essa expectativa, pois sei que só assim conhecerei o olhar do produtor visual do álbum, muito embora eu tenha uma maneira muito pessoal de apreciar as imagens fotográficas de uma cidade. Logo de saída, o editor deixa clara a sua pretensão de apresentar a cidade através de uma reportagem fotográfica, ou seja, objetivamente documentada nas imagens. A fotografia, dessa maneira, é apresentada em sua função de registro, objetivo a partir do qual é inegável a feição higiênica, moderna e bela de Porto Alegre.

A primeira página visual do álbum traz, à direita, a imagem de uma edificação imponente, a Prefeitura Municipal (fotografia 1) e, à esquerda, o retrato em formato oval e em perfil do prefeito Alberto Bins. Na página ao lado, uma imagem da Praça Marechal Deodoro e do Palácio do Governo, tendo ao seu lado a Igreja Matriz (fotografia 2). Eu poderia mencionar apenas as estruturas materiais presentes nessas imagens, mas, em frente ao Palácio do Governo há uma aglomeração de pessoas à qual não posso deixar de fazer alusão. Trata-se de uma parada militar, na qual soldados enfileirados marcham enquanto são observados por um grupo de pedestres contidos por dezenas de soldados que formam uma barreira, deixando uma grande área vazia à disposição do desfile.

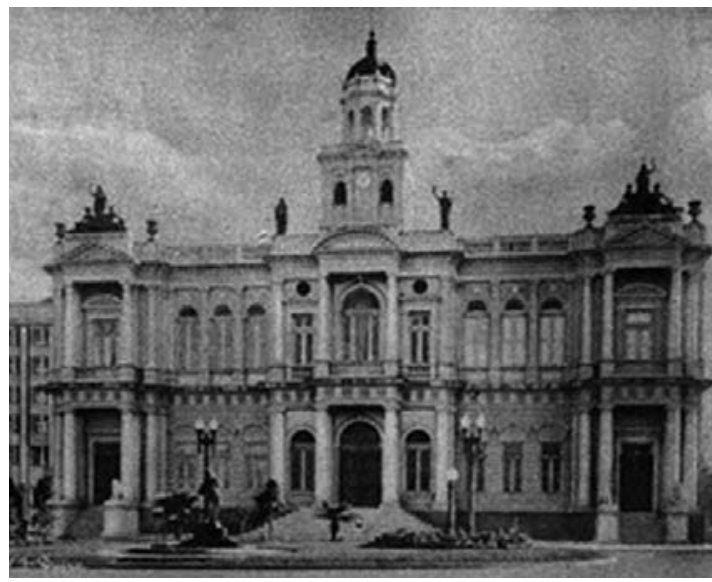

Fotografia 1 - Prefeitura Municipal de Porto Alegre. (legenda original) Fonte: CARVALHO, P. (Ed.) Porto Alegre álbum. Porto Alegre: A Noite, 1931. Acervo: MJJF/MCSHJC. 


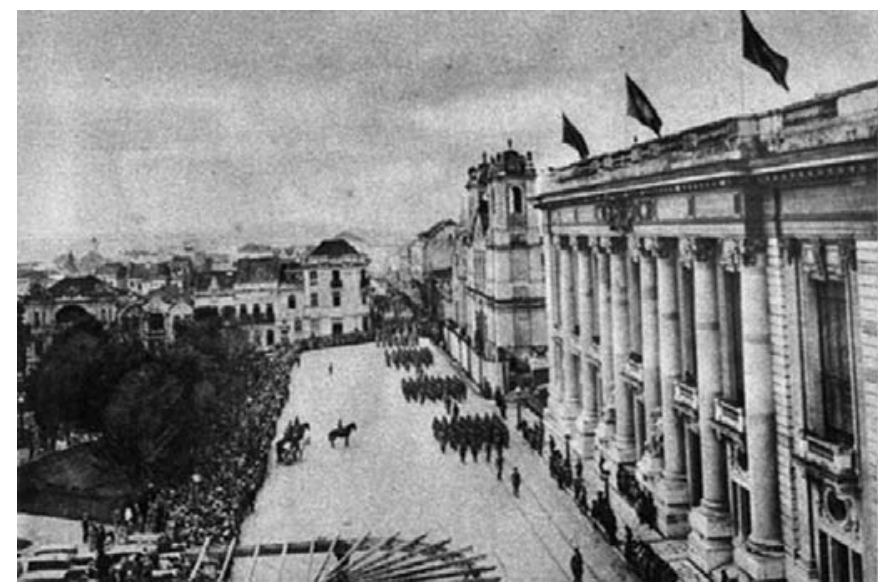

Fotografia 2 - Palácio do Governo - Ao lado, a antiga catedral, hoje demolida, erguendo-se, atualmente, em seu lugar, o majestoso monumento que será a futura catedral. (legenda original)

Fonte: CARVALHO, P. (Ed.) Porto Alegre álbum.

Porto Alegre: A Noite, 1931.

Mesmo tratando-se de um álbum de edição privada, chamou-me a atenção a reverência às autoridades políticas municipais e estaduais. O retrato do prefeito Alberto Bins assinala a autoria da obra realizada na cidade a ser vista no álbum, não deixando de fazer referência a sua íntima relação com o executivo estadual. A parada militar, ademais, coloca em cena um baluarte doutrinário dos positivistas, a ordem, considerada por eles como único meio através do qual seria possível alcançar o progresso material da sociedade.

Assim, as primeiras imagens contidas em Porto Alegre Álbum falam de poder político, autoridade, afinidade partidária e ordem, tendo como elementos visuais estruturas arquitetônicas que representam essas idéias na configuração do espaço urbano da cidade. Ao serem dispostas em primeiro lugar no álbum não deixam dúvidas quanto à convicção de seu produtor visual/colecionador de vistas de que o poder político vem em primeiro lugar, sendo seus representantes na cidade, no Estado e no Partido as autoridades máximas.

Continuo minha caminhada pelas páginas de Porto Alegre Álbum. Observo que as primeiras 19 imagens fotográficas do volume são dispostas unitariamente em cada página, seguidas por páginas que reúnem agrupamentos entre duas e cinco imagens, intercaladas com imagens isoladas. As listagens seguintes mostram a quantidade de imagens isoladas e agrupadas no corpo da publicação, assim como a forma de distribuição desses arranjos na sua seqüência: 
Quantidade de imagens isoladas

e agrupadas em Porto Alegre Álbum

Imagens isoladas 19

Agrupamentos de 2 imagens 30

Agrupamentos de 3 imagens 3

Agrupamentos de 4 imagens 2

Agrupamentos de 5 imagens 1

Seqüência dos arranjos de imagens isoladas

e agrupadas em Porto Alegre Álbum

Imagens isoladas 19

Agrupamentos de 2 imagens 10

Imagens isoladas 2

Agrupamentos de 2 imagens 2

Agrupamentos de 3 imagens 1

Imagens isoladas 1

Agrupamentos de 2 imagens 4

Agrupamentos de 3 imagens 1

Agrupamentos de 2 imagens 13

Agrupamentos de 4 imagens 1

Agrupamentos de 5 imagens 1

Agrupamentos de 4 imagens 1

Agrupamentos de 2 imagens 3

Essa disposição que privilegia as imagens isoladas na primeira parte da publicação dá certo ritmo ao meu vagar e caracteriza o meu olhar sobre essas imagens e a cidade ali representada. Detenho-me em cada imagem um tempo relativamente longo, contemplo a paisagem, percorro círculos, retorno ao ponto de partida, visito e revisito lugares, procuro o tridimensional na superfície plana. Caracterizo meu percurso visual em Porto Alegre Álbum como um 'olhar detido', propiciado pelo ritmo proposto pelo editor/colecionador, sem acelerar o passo. Tal como a cidade que primeiramente se afirma para caminhar no itinerário em busca do moderno, ainda não desejando se arriscar a correr na velocidade mecânica impingida pelas novas máquinas.

Vou folheando sem me deter em nenhuma imagem. Logo percebo que algumas delas rompem com meu olhar horizontal, exigindo que eu manuseie o álbum na vertical ou proceda a um gesto contorcionista perigoso àqueles de mais idade, da mesma forma como faço nas ruas, quando observo os altos edifícios. E, se não foi essa a intenção do seu editor, o leitor visual poderá aqui já se deter e observar a mudança de olhar e atitude corporal necessária no lei- 
tor do álbum e no leitor da cidade que flana por suas ruas. As edificações de maior altura exigem que o olhar sofra uma ruptura na monótona linha horizontal de fachadas de um ou no máximo dois pavimentos dos sobrados. Assim como rompem com as fachadas horizontais no espaço urbano para serem contidas no álbum, as imagens das edificações mais altas da cidade separam-se da seqüência de imagens urbanas horizontais.

Eis, então, uma característica digna de nota. As imagens em formato horizontal abarcam continuidades maiores do espaço urbano da cidade. Possibilitam tomadas de grandes extensões, nas quais predomina a arquitetura remanescente do período colonial, composta por construções singelas e de poucos pavimentos. Em contraste com essas edificações, destaca-se nas imagens uma arquitetura suntuosa que predomina em edificações públicas, como o Paço $\mathrm{Mu}$ nicipal, o Palácio do Governo, a Delegacia Fiscal e o Superior Tribunal. É impossível não observar que essas grandiosas estruturas monumentalizam o espaço urbano, dando um aspecto senhorial a Porto Alegre. Apesar dessa feição imponente, essa arquitetura é apresentada em continuidade àquela de aspecto menos rebuscado. Ambas são vistas em imagens de tomadas horizontais, em que o contexto urbano é sempre valorizado. Assim está, por exemplo, o Palácio do Governo (fotografia 2). Diferentemente dessas imagens de edificações públicas, as edificações de maior número de pavimentos são mostradas em imagens verticais que isolam o edifício do seu contexto, valorizando-o em sua unidade morfológica. Essas gigantescas construções têm predominância de utilização privada, em atividades comerciais, hoteleiras ou bancárias. Uma rara imagem da Praça Quinze de Novembro apresenta uma edificação de uma dezena de pavimentos ao fundo (fotografia 5). Esse alto edifício apreciado em seu contexto torna visí-

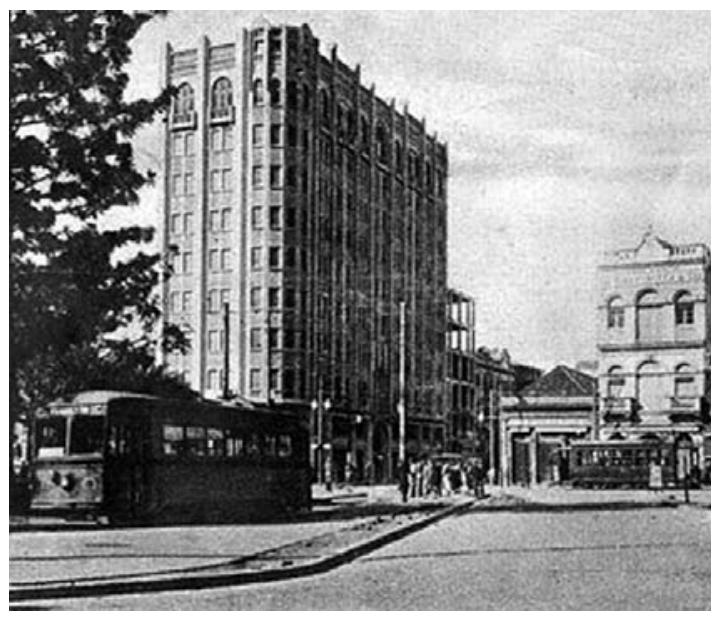

Fotografia 5 - Um recanto da Praça 15 de Novembro. (legenda original). Fonte: CARVALHO, P. (Ed.) Porto Alegre álbum. Porto Alegre: A Noite, 1931. Acervo: MJJF/ MCSHJC. 
vel talvez o que se desejou ocultar nas demais tomadas verticais de edifícios isolados. Edificações de altura elevada em algumas áreas da cidade, mesmo em se tratando da área central, eram exceções no contexto urbano ainda marcado pelos baixos casarios coloniais, muitos erigidos ainda no século XVIII.

Esqueço momentaneamente a narrativa seqüencial do álbum fotográfico, indo à procura de outras imagens no mesmo padrão de uma que me chamara especialmente a atenção, a imagem do Grande Hotel, localizado na esquina da Rua da Praia com a Rua Paissandu (fotografia 6). Encontro apenas uma segunda imagem, apresentada anteriormente a essa do Grande Hotel. Trata-se do Banco da Província (fotografia 3), edificação suntuosa nos mesmos moldes do ecletismo das edificações públicas já mencionadas. Esta, porém, busca a monumentalidade, preocupando-se em marcar urbanisticamente a esquina por meio do seu corpo arredondado e de sua cúpula. Grandes colunas verticalizam a edificação de poucos pavimentos que, mediante referências clássicas, tende para o tradicional.

Assinalo, então, que há apenas duas imagens de edificações na edição, privilegiando o formato vertical e isolando o prédio do seu contexto urbano. Assim, a imagem do Grande Hotel valoriza o desenho, que tende para uma linguagem modernizante, no qual as referências clássicas são discretas. A edificação conforma o quarteirão, embora tenha outros prédios no seu lado esquerdo. A fotografia, ao isolá-la da paisagem urbana do seu entorno, transfere a mesma imagem ao restante da cidade, apesar de não ser esta a configuração estrutural das edificações lindeiras. Essa percepção é corroborada em ima-

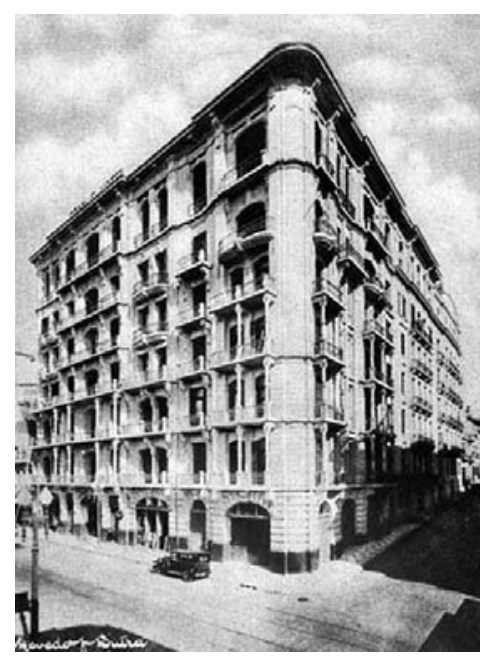

Fotografia 6 - Rua dos Andradas, esquina Paisandú. (legenda original)

Fonte: CARVALHO, P. (Ed.) Porto Alegre álbum. Porto Alegre: A Noite, 1931. Acervo: MJJF/MCSHJC. 


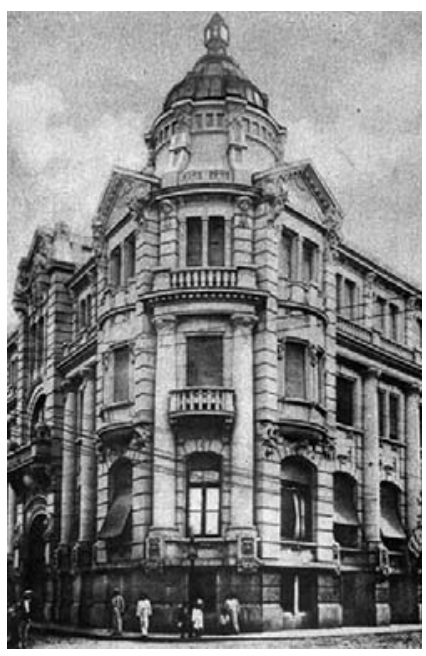

Fotografia 3 - Banco da Província do Rio Grande do Sul - Tradicional estabelecimento Bancário riograndense (sic). (legenda original)

Fonte: CARVAlHO, P. (Ed.). Porto Alegre álbum. Porto Alegre: A Noite, 1931. Acervo: MJJF/MCSHJC.

gem na seqüência em que a mesma edificação do Grande Hotel é vista a partir da Praça da Alfândega, na qual se deixa à mostra o prédio limítrofe, localizado na mesma quadra e ao seu lado na outra esquina da Rua da Praia e da Rua Paissandu, a edificação da sede do jornal A Federação. Tendo poucos pavimentos, esta contrasta estruturalmente com o alto edifício.

A partir dessas observações, posso considerar que as imagens das edificações de altura mais elevada, em especial a imagem do Grande Hotel, tiveram no conjunto selecionado o objetivo de representar visualmente uma tendência em direção à modernidade urbana de Porto Alegre, por constituírem, os altos edifícios, um signo distintivo do imaginário moderno. Além disso, o fotógrafo captou a imagem da edificação no exato instante em que estrategicamente estava estacionado em frente à sua fachada principal um automóvel, também signo indiscutível da modernidade, por representar não apenas a tecnologia, capaz de transportar o homem através do espaço, mas também a velocidade, baluarte dos novos tempos.

Observei, entretanto, constituírem minoria essas imagens no interior do álbum, levando a pensar que a modernidade urbana por elas conformada apenas se insinua em estruturas recentemente erigidas, não vindo ainda a marcar o desenho arquitetônico de Porto Alegre. Dessa forma, se por um lado, aqui se quis representar visualmente um imaginário de modernidade urbana, através de um edifício isolado, o Banco da Província, a cidade ainda com traços coloniais predominantes trai o fotógrafo e, quem sabe, o colecionador. Na rua, em frente à edificação, à esquerda, no ângulo inferior da imagem um 
quadrúpede deixa às claras o aspecto colonial da Porto Alegre que ainda dispunha de veículos e transporte a tração animal circulando na sua área central. Contraste maior com a imagem do Grande Hotel não há, e imagino o sorriso irônico do flâneur ao constatar esse detalhe. O que terá havido? Não quis o fotógrafo aguardar o momento exato em que tal cena seria mais bem arquitetada com vistas a uma imagem de cidade moderna? Quis ele justamente deixar explícita a dicotomia vivida entre o colonial e o moderno no espaço urbano? Difícil encontrar respostas seguras.

Essas indagações me fazem retornar o pensamento à cadência do meu andar visual. Esse ritmo compassado coaduna-se com a feição da cidade naquele momento, ainda com traços de sua pacata e bucólica vida colonial, mas com os olhos voltados para uma modernidade que se avizinhava e que já passava a modificar a paisagem urbana. Num diálogo com a cidade, o álbum de suas imagens urbanas me conduz. Vendo as imagens e procurando ler a narrativa que elas contêm, adentro também o texto complexo da cidade.

Talvez, mesmo sendo desejo das elites porto-alegrenses moldar o espaço urbano e a vida dos habitantes de Porto Alegre de acordo com um imaginário exclusivamente moderno, as estruturas materiais da cidade e o comportamento dos que viviam nela mudassem consoante um ritmo mais lento e propenso à longa duração. Nessa direção, Sandra Pesavento mostra como no fin de siècle as imagens literárias de Porto Alegre oscilavam entre a aldeia e a metrópole. ${ }^{20} \mathrm{~A}$ efervescência dos cafés e dos teatros e o rebuliço nas ruas na hora do footing contrastavam com arrabaldes de características ainda rurais e com uma população de costumes ainda provincianos, entre os quais ocupar-se da vida alheia era hábito ainda comum.

Mas, talvez, isso importasse pouco no âmbito do imaginário visual cuidadosamente criado por essas imagens fotográficas e pelo álbum que as reúne num todo orgânico. Importasse, talvez, que a imagem preponderante é a de Porto Alegre como uma cidade moderna. Mais ainda, nas imagens fotográficas reunidas pelo álbum, ensaiava-se também um novo olhar sobre a cidade, que, por sua vez, criava uma nova visualidade. No caso da imagem do Banco da Província, é a edificação que impera majestosa, apesar do burrico que perturba a vista de sua fachada. Tanto o fotógrafo quanto o colecionador do álbum privilegiaram os elementos icônicos que, mal ou bem, atestavam a modernidade urbana, tentando inaugurar uma visualidade da cidade em conformidade com esses referentes, da mesma maneira que operaram escritores e cronistas ao deixarem o registro de suas sensibilidades sobre a cidade.

Dessa forma, as imagens mentais do imaginário moderno tomam forma visual nas fotografias produzidas e reunidas, confundindo-se com a realidade. 
São textos que se transformam em imagens técnicas, concebidas como registros fidedignos do real. Estas, por sua vez, ao serem interpretadas, são novamente decodificadas em textos, nos quais emergem aspectos que escaparam ao controle do fotógrafo ou que revelam seus artifícios. A imagem fotográfica, assim, por estar envolvida no processo de criação de realidades, ${ }^{21}$ desde a sua produção até a sua utilização, segundo determinadas interpretações, como é o caso dos álbuns fotográficos, expressa um conflito latente entre o visível e o invisível. A imagem do Banco da Província é um bom exemplo dessa tensão, pois ao ser elaborada ou inserida em Porto Alegre Álbum com a finalidade de representar visualmente a modernidade urbana, apresenta elementos que contradizem a interpretação ou leitura proposta pelo produtor visual da imagem. Se a intenção era elaborar através da fotografia uma imagem da cidade moderna, observa-se que na visualidade fotográfica construída da cidade o moderno está presente como desejo, moldando um imaginário que pulula nas mentes citadinas e que se concretiza, não tanto na totalidade de uma cidade que ainda carrega na sua espacialidade estruturas coloniais, mas na visualidade configurada pelas imagens fotográficas e pelos álbuns fotográficos.

As vistas aéreas presentes em Porto Alegre Álbum reforçam essa interpretação. Nesse álbum estão presentes três vistas aéreas: a primeira está disposta na página ao lado da imagem vertical da edificação do Banco da Província e tem como objeto a ponta do promontório e a orla que contorna a área central em direção à Zona Norte, onde se localizavam os bairros industriais (fotografia 4); a segunda é uma tomada da Praça Marechal Deodoro (fotografia 7), que

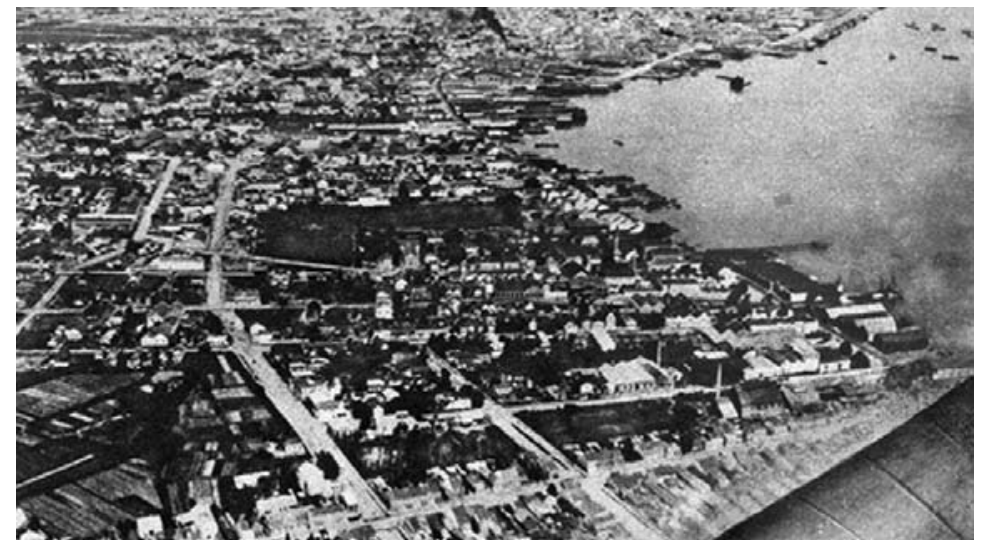

Fotografia 4 - Vista aérea de uma parte de Porto Alegre. (legenda original). Fonte: CARVALHO, P. (Ed.) Porto Alegre álbum. Porto Alegre: A Noite, 1931. Acervo: MJJF/MCSHJC. 


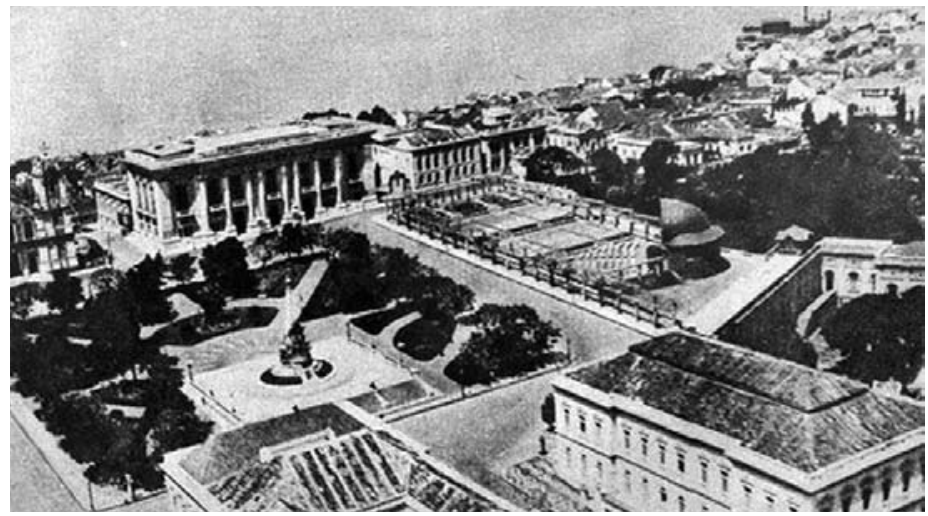

Fotografia 7 - Vista aérea da Praça Marechal Deodoro. (legenda original) Fonte: CARVALHO, Pedro. (Ed.) Porto Alegre álbum. Porto Alegre: A Noite, 1931. Acervo: MJJF/MCSHJC.

está associada à imagem do mesmo espaço disposta à página à esquerda. Nessa última vista aérea, o lago descortina-se ao fundo da praça, dando uma feição bucólica à cidade. A terceira está disposta várias páginas após as outras duas e impressa em papel de qualidade e dimensão diferenciadas daquele do restante do álbum. A página dobra-se em quatro partes para ser contida no tamanho do álbum. A vista é um panorama da área central da cidade, tendo em destaque o Cais do Porto e as embarcações atracadas no Lago Guaíba, no qual se pode observar o delineamento da ponta da península (fotografia 16).

Se algumas imagens isolam o objeto fotografado, subtraindo-o do con-

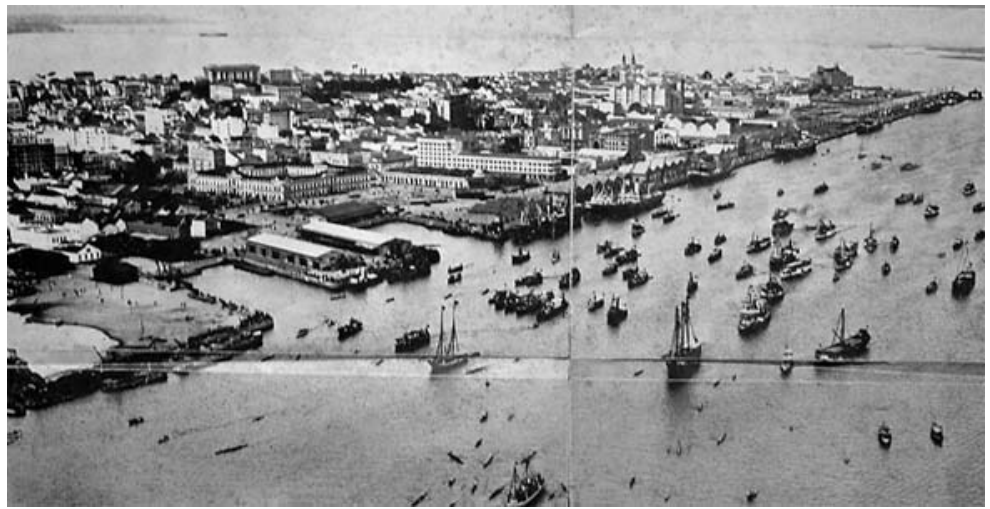

Fotografia 16 - Fonte: CARVALHO, P. (Ed.) Porto Alegre álbum. Porto Alegre: A Noite, 1931. Acervo: MJJF/MCSHJC. 
texto urbano, em oposição a elas a vista aérea pretende abarcar considerável contigüidade espacial em uma única tomada. Nesse aspecto, a vista aérea revela uma das maiores peculiaridades das vistas urbanas, qual seja a sua capacidade de redução da escala colossal da cidade, tornando perceptíveis aspectos do desenho urbano. A primeira imagem é elucidativa nesse aspecto, pois o traçado da ponta da península exige distanciamento e redução de escala para ser abarcado pelo olhar, e a vista a vol d'oiseau é, nesse sentido, eficaz em tornar visível esse contorno geográfico. A vista aérea é exemplar de uma mudança de relação entre o olhar e o espaço, ${ }^{22}$ tornando este passível de ser alcançado por aquele. A vista aérea ao privilegiar uma macro-visão do urbano em detrimento de estruturas que possam ser valorizadas, como as edificações mencionadas anteriormente, contribui para a percepção da idéia de cidade na perspectiva da nascente disciplina do urbanismo que passava a pensá-la em sua totalidade, buscando resolver os seus problemas urbanos através da elaboração de planos a serem concretizados ao longo de várias décadas e não por ações pontuais e isoladas.

Além disso, a vista aérea incorporou na própria elaboração de uma nova visualidade da cidade e de seu espaço urbano um elemento móvel, o avião, a partir do qual as tomadas eram realizadas. $\mathrm{O}$ avião pode ser considerado mais um elemento icônico distintivo da modernidade, por condensar numa única máquina as possibilidades tecnológicas da modernização. Através dele não apenas chegou-se aos ares, sobrevoando a terra, como se alcançou uma velocidade extraordinária não conseguida em terra firme até então. A realização de vistas fotográficas tomadas do avião possibilitou alterações significativas na visualidade fotográfica, em especial na visualidade da cidade. Assim, a mobilidade do ponto de observação do olhar fotográfico, bem como a sua suspensão sobre o objeto são características diferenciadoras dessa nova visualidade, que tem nos meios tecnológicos recém-inventados novas possibilidades de percepção visual e de criação de imagens.

A instabilidade do objeto a ser observado é uma das rupturas trazida pelos experimentos fotográficos realizados nessa época, sendo o leitor visual convidado a explorar vários pontos de vista. ${ }^{23}$ Daí as fotografias aéreas condensarem várias modificações na visualidade da cidade. É o ponto de observação que adquire mobilidade e, conseqüentemente, o objeto a ser fotografado também se move, possibilitando a apreciação de muitos ângulos de visão em um único sobrevôo. As vistas aéreas urbanas, nesse sentido, são imagens síntese da modernidade por representarem o dinamismo e o movimento, fruto das alterações urbanas, e por possibilitarem incorporar diferentes pontos de vista sobre a cidade de um ponto de observação também móvel.

Dessa maneira, as vistas aéreas de Porto Alegre presentes no álbum ates- 
tam para o leitor visual o compasso em que se encontrava a capital do Rio Grande do Sul em relação às inovações tecnológicas em curso em outros cantos do planeta, ao mesmo tempo em que inauguravam uma nova visualidade dessa cidade, na qual as possibilidades técnicas e estéticas propiciadas pelas tomadas a partir de um instrumento aéreo móvel produziam uma imagem diferenciada e até então não conhecida da cidade. Isso significa afirmar que não apenas o avião fazia parte do cotidiano da vida porto-alegrense na década de $1930,{ }^{24}$ como os artistas-fotógrafos estavam em sintonia com as inovações estéticas criadas por seus colegas de métier em outras partes do mundo, não deixando de elaborar, aqui também, imagens em consonância com esses novos padrões. Há que ressaltar, porém, que essa sintonia se adequava apenas aos parâmetros formais, pois a Porto Alegre daquela época era uma cidade com traços coloniais e ainda ensaiando seus passos em direção a uma modernidade pretendida. Isso quer dizer que esses artistas fotógrafos ainda não dispunham de elementos estruturais urbanos que possibilitassem vôs mais arrojados, como aqueles praticados por artistas-fotógrafos como Moholy-Nagy e Mendelsohn, ${ }^{25}$ que tiveram na cidade verticalizada dos arranha-céus suas maiores inspirações.

Merece destaque, também, a incorporação de parte da asa do avião em uma das imagens aéreas presentes no álbum (fotografia 4). Poder-se-ia atribuir esse detalhe a um descuido do fotógrafo. No entanto, interpreto esse aparente 'descuido' como intenção do fotógrafo em deixar visível na fotografia o seu ponto de observação. Talvez fosse desnecessário esse registro de forma tão redundante, no entanto, assinala o fotógrafo como sujeito dinâmico por buscar um ponto de vista considerado inovador e inusitado para aquela época. Reforça essa idéia a legenda da última vista aérea presente no álbum (fotografia 16), Panorama aéreo de uma parte de Porto Alegre, vista tomada de avião, por Kurt Geissler, quando situa com exagerado detalhe, como se necessário fosse mencionar, a posição adotada pelo fotógrafo.

Além de novos posicionamentos do olhar fotográfico, a incorporação do dinamismo é uma das marcas da nova visualidade fotográfica que é inaugurada ao lado de um conjunto de alterações pelas quais passaram as cidades no processo de modernização. A arquitetura das cidades constituiu-se em objeto privilegiado para a elaboração das primeiras imagens fotográficas, pois estas requeriam objetos estáticos em razão das limitações técnicas. ${ }^{26}$ As pessoas em movimento que porventura cruzassem o quadro selecionado pelo fotógrafo nada mais seriam que fantasmas na imagem posteriormente revelada. Na cidade moderna, ao contrário, multiplicaram-se as confluências e in- 
tersecções de vias de circulação no traçado urbano, assim como aumentaram os fluxos de veículos e pessoas. Captar essa dinâmica dos deslocamentos, representando a mobilidade urbana na imagem, foi uma das tarefas da fotografia. Esse objetivo foi alcançado pela incorporação de elementos em movimento no espaço urbano, como transeuntes e veículos, assim como pelo deslocamento do ponto de observação em relação ao objeto a ser fotografado, como era o caso das vistas aéreas. ${ }^{27}$

Retorno, então, à narrativa de Porto Alegre Álbum. Após a primeira vista aérea da cidade, temos a imagem da Praça Quinze de Novembro, seguida das imagens das edificações da esquina da Rua Paissandu com Rua dos Andradas e do Superior Tribunal, ambas já mencionadas. Após esta última imagem, o álbum apresenta uma imagem da Praça Senador Florêncio, seguida por duas imagens da Praça Marechal Deodoro, dispostas lado a lado, sendo a última uma vista aérea também já mencionada anteriormente. Continuando o percurso, segue uma imagem da edificação do Mercado Público, disposta ao lado de mais uma imagem da Praça Senador Florêncio. Após duas imagens comparativas da cidade, às quais retornarei adiante, seguem mais duas imagens de praças, da Praça Senador Florêncio disposta ao lado de outra imagem da Praça Marechal Deodoro, tendo em destaque o Auditório Araújo Viana.

Nessa seqüência de imagens o editor intercalou com imagens de edificações ou de vistas aéreas imagens de praças do centro da cidade. Ou ainda dispôs lado a lado esse mesmo elemento icônico, fazendo notar, pela recorrência ao tema, uma área do espaço urbano a ser valorizada pelo leitor visual no conjunto de imagens selecionadas, as praças. De fato, as praças localizadas na área central de Porto Alegre receberam especial consideração nas reformas urbanas implementadas a partir dos anos 20. A higienização e o embelezamento da cidade são os motivos essenciais para o investimento nessas áreas.

Ademais, as praças foram realçadas, no álbum, por constituírem cenário das novas sociabilidades urbanas a serem também salientadas. Nessa perspectiva, há que ressaltar a presença de transeuntes na maioria dessas imagens fotográficas, principalmente aquelas da Praça Quinze de Novembro e da Praça Senador Florêncio. Na imagem da Praça Quinze um grupo de pessoas aparece ao fundo da imagem à espera do transporte coletivo, enquanto em primeiro plano o bonde elétrico é valorizado como forma de atestar a modernização dos transportes na cidade. Nas três imagens da Praça Senador Florêncio a presença das pessoas pode ser observada em diferentes situações, tais como circulando por seus passeios, caminhando acompanhadas ou estando sentadas em seus bancos. Dessa forma, as imagens fotográficas, ao colocarem pes- 
soas no espaço público fotografado, conferem grande dinamicidade à imagem visual da cidade. $\mathrm{O}$ espaço, porém, não é uma área aleatória, mas determinado largo especialmente preparado, remodelado, embelezado e modernizado para recebê-las. Esses pedestres que circulam pelo espaço urbano nessas imagens são, em sua maioria, usuários do transporte coletivo, homens, sozinhos ou acompanhados, conversando, representando situações de descanso ou de lazer. Nas imagens visuais dá-se, assim, visibilidade ao grupo social que freqüentaria esses lugares, notadamente as classes mais abastadas, que disporiam de tempo livre para realizar o footing pelos novos espaços planejados. Não observo nessas imagens homens trabalhando ou mulheres, ainda restritas ao espaço privado de suas residências. As imagens fotográficas, assim, dão visibilidade a sujeitos e comportamentos socialmente desejados, retirando da cena urbana aqueles sujeitos e situações que se desejava invisíveis.

A imagem da Praça Marechal Deodoro, tendo em destaque o Auditório Araújo Viana (fotografia 10), é elucidativa a esse respeito, apresentando vários aspectos a considerar. Não são algumas pessoas dispersas pelo espaço urbano que são mostradas, mas dezenas de espectadores reunidos por ocasião de uma apresentação da Banda Municipal. Essa imagem, assim, torna evidente um personagem que surge com o advento das metrópoles e da própria modernidade, a multidão, tão bem descrita por Edgar Allan Poe em seu célebre conto "O homem da multidão". ${ }^{28}$ Assim, em termos visuais essa imagem foto-

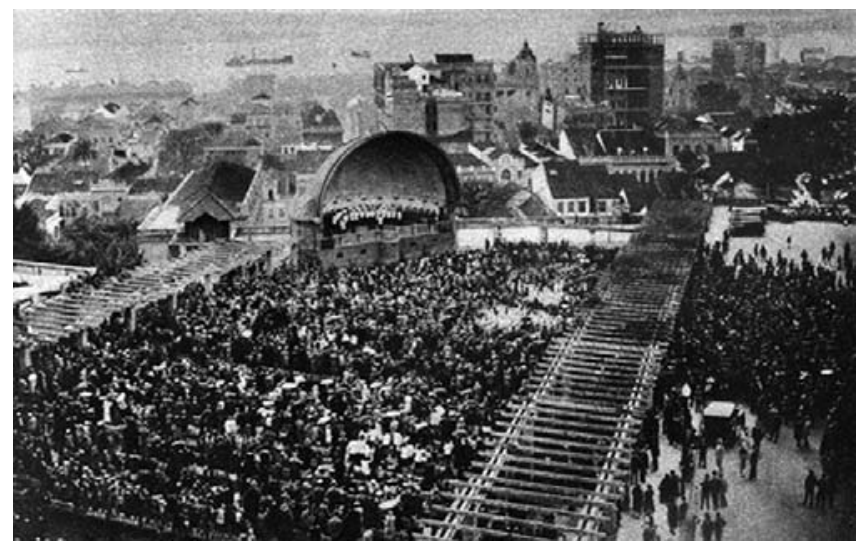

Fotografia 10 - Auditorium Araujo Viana (todo de concreto armado). Local onde se realisam $[s i c]$ concertos públicos pela Banda Municipal. (legenda original) Fonte: CARVALHO, P. (Ed.) Porto Alegre álbum. Porto Alegre: A Noite, 1931. Acervo: MJJF/MCSHJC. 
gráfica oferece à vista uma presença já constatada em outras grandes cidades e já captada pelas lentes dos fotógrafos de Porto Alegre.

Porém, essa imagem deixa explícita a função planejada para a Praça Marechal Deodoro - Cidade Alta, que congregava desde sua origem no século XVIII as funções governamentais e eclesiásticas - como lugar de realização de espetáculos ao ar livre, intento concretizado com a construção do auditório. Deixa, assim, também explícito o recorte social e o tipo de atividade pretendidos na utilização do espaço público das praças — atividades de lazer e entretenimento dirigidas como espetáculos ao gosto da época. Essa imagem fotográfica, assim, dá visibilidade ao ideal almejado de configurar um cenário pelo qual circula a burguesia porto-alegrense. Fotografando a multidão, o autor ainda confere alto dinamismo à imagem urbana, aproximando a imagem visual de Porto Alegre de uma cidade moderna, cujo espaço público embelezado pode ser ocupado para práticas sociais da vida mundana.

O flâneur observa que as imagens de Porto Alegre Álbum privilegiam o espaço urbano, as estruturas, as ruas, as edificações, os largos, as praças, enfim, tudo aquilo que dá feição material à cidade. A área central é o espaço privilegiado das tomadas, em sintonia com a idéia de que essa é a área mais importante da cidade a ser visualizada, principalmente pelo fato de estar concentrando nos últimos anos os investimentos para as obras de sua remodelação.

Ainda na cidade de pedra de Porto Alegre Álbum noto a presença dos porto-alegrenses transitando pelas ruas e calçadas. A rua adquire visualmente um novo significado na cidade moderna, ${ }^{29}$ vindo a constituir, ao lado de outros espaços como os cafés, ponto de encontro da população. É o espaço da rua, dessa forma, o articulador da circulação, dos acessos a lojas, aos cafés e às livrarias. É a rua, também, que melhor caracteriza a experiência mundana da modernidade, por jogar no âmbito público a presença do indivíduo, tornando-o passível dos olhares que o rodeiam. A rua, mais que qualquer outro lugar do espaço urbano, adquire especial significado na elaboração de uma visualidade em consonância com o ideal de uma cidade moderna e de um novo imaginário social. Nessa perspectiva, as imagens fotográficas de ruas presentes em Porto Alegre Álbum desejam expressar sentidos precisos, como é o caso de duas imagens da Rua dos Andradas, em épocas distintas, dispostas lado a lado e que pretendem sintetizar visualmente as transformações pelas quais passou a cidade. A imagem mais antiga remonta a 1870, segundo legenda explicativa do álbum (fotografia 8), constituindo trecho da Rua dos Andradas, e a segunda imagem é contemporânea à publicação do Álbum, referindo-se à esquina da Rua dos Andradas com a Rua General Câmara (fotografia 9), conhecida por Largo dos Medeiros. ${ }^{30}$ 


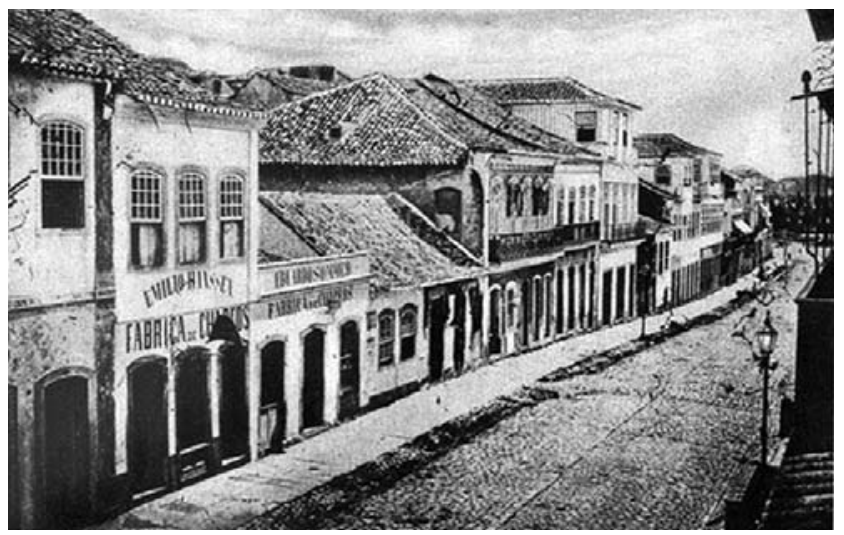

Fotografia 8 - Rua dos Andradas, em 1870. (legenda original) Fonte: CARVALHO, P. (Ed.) Porto Alegre álbum. Porto Alegre: A Noite, 1931. Acervo: MJJF/MCSHJC.

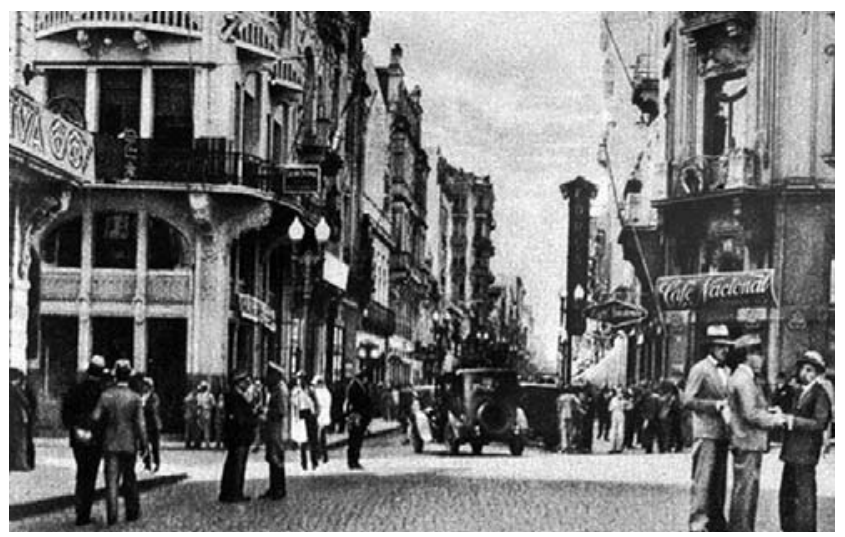

Fotografia 9 - Rua dos Andradas - 1931. (legenda original) Fonte: CARVALHO, P. (Ed.) Porto Alegre álbum. Porto Alegre: A Noite, 1931. Acervo: MJJF/MCSHJC.

A intenção comparativa na disposição das duas imagens é evidente e coaduna-se com uma prática bastante disseminada nas edições de álbuns de vistas urbanas, principalmente aqueles de edição oficial. Se fossem visualizadas separadamente, é certo que ambas as imagens não comportariam tantos signos e não viriam a criar, de maneira tão contundente, uma representação da cidade moderna e da cidade colonial. Ao serem ressaltados os atributos icônicos de determinada imagem, enfatiza-se o que se dá a ver da outra e vice-versa. 
A imagem Rua dos Andradas em 1870 é uma tomada do alto, em diagonal, recortando um quarteirão de edificações de um único pavimento ou de até três pavimentos. Nessa arquitetura de janelas em arco e de portas nas calçadas, destacam-se alguns sobrados com balcões ornamentados com gradis em ferro. Predominam os beirais, sobrepostos por telhados de barro. Em algumas edificações podem ser observadas as inscrições com as denominações dos estabelecimentos comerciais ali instalados. A rua configura-se por meio de um suave declive e uma linha tortuosa que a tomada diagonal faz o olhar acentuar ainda mais. O calçamento de pedras irregulares, calçadas estreitas e meio-fio composto por um amontoado de pedras disformes são outras características que a imagem apresenta. A iluminação da cidade está presente graças a um poste sustentando um lampião a gás.

Pequenos detalhes das edificações, do outro lado da rua, tornam visível o limite do leito da Rua dos Andradas, de modo que se acentue na imagem a sua dimensão reduzida. Esses detalhes ainda evidenciam o posicionamento do fotógrafo no lado contrário da rua ao alinhamento de casarios e ao alto, provavelmente ocupando uma janela ou sacada. A tomada com câmera alta, neste caso, provoca um distanciamento do leitor visual da imagem, fazendo com que este assuma um olhar contemplativo em relação à paisagem urbana que se descortina à sua frente.

A imagem Rua dos Andradas em 1931 é uma tomada central e horizontal da posição de um pedestre, o que permite ao leitor visual sentir-se situado na própria rua, apreciando a paisagem. Nessa escolha já se têm duas intenções discursivas visuais, a primeira desejando afastar o leitor do objeto fotografado, a cidade colonial, a segunda aspirando imergi-lo na rua da cidade moderna. A escolha de uma esquina explicita o desenho arquitetônico das edificações de vários pavimentos e de traços ecléticos, que seguem o alinhamento da rua em direção ao infinito. Ao posicionar-se no centro da rua, o fotógrafo potencializou a característica de largo da área, ampliando, sobremaneira, o leito da rua. Ao serem vistas juntas, as duas imagens dão a ilusão de que a Rua dos Andradas sofrera um alargamento considerável, o que não ocorreu.

A tomada a partir da esquina ainda permite que se coloque na cena determinado ponto do traçado urbano de confluência de pessoas e veículos, dando grande dinamismo à imagem. São pedestres, grupos de pessoas, em sua maioria do sexo masculino, paradas a conversar, um guarda, um jornaleiro, um automóvel dobrando a esquina. A imagem, assim, busca representar fotograficamente um dos principais atributos do urbano moderno vistos anteriormente, o movimento. Todos esses elementos móveis permitem, dessa 
forma, representar a cidade em sua dinâmica, não deixando de contemplar, mais uma vez, a multidão, graças ao aglomerado de pessoas num único espaço, sem deixar de fazer menção às novas sociabilidades mundanas ensaiadas pela burguesia ao gosto francês da época, representadas na imagem fotográfica pelas inscrições do Café Nacional e do Salão Colombo.

Esse talvez seja o aspecto no qual as duas imagens apresentam maior contraste. Na imagem da cidade colonial a rua se apresenta vazia, sem a presença de nenhum transeunte ou veículo. Desprovida de qualquer elemento móvel, são ressaltadas, assim, suas características de repouso e imobilidade, traços que dão à Porto Alegre colonial uma imagem de cidade pacata, singela, estática. A Porto Alegre moderna, ao contrário, descortina-se dinâmica, efervescente, múltipla em suas atividades urbanas, representadas pelo guarda de trânsito, pelo jornaleiro, pelos cafés e pelo automóvel.

Dessa maneira, os traços da cidade colonial apresentados procuram salientar, através da imagem fotográfica, o distanciamento entre essas duas cidades, acentuando as modificações ocorridas no intervalo entre os dois registros, na sua principal artéria. A Rua dos Andradas do final do século XIX é, assim, dada a ver nessa imagem como uma rua estreita, tortuosa e singela, configurando uma feição pacata à Porto Alegre de então. No entanto, outras informações que busquei sobre essa rua, denominada por várias décadas por Rua da Praia, não condizem com essa imagem fotográfica, como pode ser analisado, por exemplo, nesta passagem deixada pelo naturalista francês Auguste Saint-Hilaire quando visitou a cidade entre os anos de 1820 e 1822:

A Rua da Praia, a única comercial, é extremamente movimentada. Nela se encontram numerosas pessoas a pé e a cavalo, marinheiros e muitos negros, carregando fardos. É provida de lojas muito bem instaladas, de vendas bem sortidas e de oficinas de várias profissões. ${ }^{31}$

Se em 1820 a Rua da Praia apresentava-se aos olhos de um estrangeiro com tal movimento, é de supor que cinqüenta anos após essa efervescência só tenha aumentado, tendo em vista o crescimento da cidade, principalmente a partir do momento em que se tornou, na segunda metade do século XIX, o principal porto de escoamento dos produtos oriundos das colônias imigrantes do estado.

Examinando outras imagens fotográficas de ruas da cidade cuja produção é atribuída ao final do século XIX, pude observar a presença de vários elementos móveis, como animais, transeuntes e veículos a tração animal. O que 
observo nessas imagens é uma cidade com traços materiais coloniais, principalmente representados pela arquitetura dos casarios e dos sobrados, mas que deixam à mostra a dinâmica e o movimento das vias urbanas, próprios do fin de siècle porto-alegrense. Mulheres indo às compras ou mesmo vendendo algum produto, pedestres nas calçadas, veículos em movimento ou parados, animais domésticos. Mesmo os 'fantasmas' presentes nessas imagens oferecem à vista o movimento, não captado satisfatoriamente pelos recursos técnicos da época.

Por tais considerações, a disposição lado a lado das duas imagens da Rua dos Andradas em Porto Alegre Álbum, logo após o vislumbre de algumas imagens da cidade na década de 1930, permite pensar no desejo do produtor da edição em explicitar visualmente os aspectos mencionados. A escolha dessa imagem de 1870 não é, portanto, aleatória. Ao contrário, foi selecionada por conter elementos icônicos e formais que permitissem melhor visibilidade dos aspectos a serem valorizados na imagem de 1931. Nessa perspectiva, as duas imagens em conjunto constroem uma trama visual não perceptível se ambas estivessem apresentadas em separado e isoladas no álbum. Assim, o diálogo travado entre as duas imagens permite criar e veicular uma narrativa que fala da cidade colonial, da cidade moderna e das transformações urbanas que tornaram possível o desaparecimento de uma e o surgimento de outra.

Além disso, ambas sintetizam de alguma maneira a própria narrativa construída por Porto Alegre Álbum, deixada às claras no texto introdutório da edição. Sendo intenção dos editores dar a ver uma cidade moderna, higiênica e bela no ano de 1931, a única imagem anacrônica de todo o conjunto está ali presente com um objetivo bastante claro: dar visibilidade aos aspectos modernizadores de Porto Alegre presentes na outra imagem e no conjunto da publicação como um todo. Estes, ao serem colocados em contraposição àqueles presentes em outro tempo, tornam mais eloqüentes as mudanças ocorridas, valorizando a cidade do presente. Assim, as duas imagens operam com a contraposição de elementos icônicos e formais, tais como:

rua estreita / rua larga, largo

rua tortuosa / rua reta

rua vazia / rua cheia;

edificações baixas / edificações altas;

iluminação a gás / iluminação elétrica

ausência de sociabilidade pública / cafés e encontros na rua

ausência de funções / multifuncional 
repouso / atividade

arquitetura colonial / arquitetura eclética

tomada do alto (câmera alta) / tomada da vista do pedestre

ponto de vista central / ponto de vista diagonal

direção diagonal / direção centrípeta

Pelo contraste entre esses elementos é possível verificar em que medida a imagem de 1870 foi selecionada para auxiliar a construir visualmente a imagem do moderno na cidade, acentuada mediante determinados aspectos temáticos distinguidos por meio dos procedimentos formais adotados. Assim, quanto mais distante a Porto Alegre dos anos 30 estivesse visualmente daquela do final do século, de forma mais eficaz se fixaria e se propagaria como imagem da cidade moderna nas cabeças dos leitores visuais da publicação. Dessa forma, Porto Alegre Álbum não apenas constrói uma nova visualidade para a cidade do presente, como também fixa em imagem uma determinada memória visual da cidade do passado, encerrando sua existência apenas no quadro fotográfico, em imagem. Isso significa dizer que modela o imaginário em duas direções: por um lado, desenhando e matizando a cidade moderna; por outro, apagando os traços urbanos coloniais, pela transposição do moderno imaginado para a cidade e por meio do encapsulamento da cidade colonial na imagem fotográfica.

O leitor visual ao deparar-se com essas duas imagens do álbum, a despeito de ter outras leituras, tece com os fios visíveis e invisíveis à sua disposição uma urdidura na qual os traços da Porto Alegre colonial desapareceram completamente do espaço urbano, dando lugar a uma cidade de feição moderna. A imagem fotográfica da cidade colonial, assim, fixa na memória seus traços de acordo com os contornos exigidos pelo álbum, sugerindo seu apagamento e seu esquecimento do espaço e da dinâmica do presente. A cidade do presente, ao contrário, mostra-se povoada pela variedade de aspectos apresentados pelas demais imagens fotográficas da publicação. É essa a visualidade fixada como memória da cidade.

As duas imagens ainda evidenciam a noção de objetividade atribuída à fotografia. Ao serem contrapostas no interior do álbum, é intenção do editor que ambas operem enquanto testemunhos da realidade do presente e do passado da cidade. Os códigos visuais trabalham no sentido de apontar informações, supostamente objetivas da cidade, em tempo e local precisos, transformando processos em cenas. ${ }^{32}$ As imagens fotográficas comparativas presentes em Porto Alegre Álbum transformam, assim, um longo processo de modifica- 
ções do espaço urbano em cenas, provocando um efeito de ilusão. Nessa direção, a fotografia tem especial eficácia, pois, conforme Kossoy, "As imagens técnicas tornam as imagens mentais reais. As fantasias da imaginação individual e do imaginário coletivo adquirem contornos nítidos e formas concretas através do testemunho fotográfico" ${ }^{33}$

Ao serem contrapostas no álbum fotográfico essas imagens técnicas potencializaram sua capacidade ilusória, tecendo uma trama em que realidade e ficção auxiliam na composição visual. Assim sendo, paradoxalmente, a fotografia, considerada registro fidedigno do real por sua natureza, é utilizada no seu efeito visual de ilusão para ser construída como testemunho, registro comprobatório do processo que tenta mostrar.

Continuei lendo as imagens de Porto Alegre Álbum, fazendo um retorno ao início da publicação até chegar às duas imagens da Rua dos Andradas recém-analisadas e seguindo adiante. $\mathrm{O}$ 'olhar contido' instigado pelo enredo do álbum parece ter um ponto de clivagem quando se chega àquelas imagens comparativas da cidade. Alternando o olhar de uma para outra, sugere-me movimento, mudança, transformação. De algum modo a dinâmica a ser projetada para a cidade, conforme mencionei anteriormente, induz ao mesmo procedimento na observação das imagens seguintes. O meu passo parece acelerar-se quando segue adiante meu olhar, como se a própria cidade estivesse em movimento mais acelerado que aquele experimentado no início das páginas de Porto Alegre Álbum.

Uma hipótese, então, me vem à mente. Não teria o produtor do álbum percebido que as imagens que compõem o conjunto deixavam à mostra esse andar contido que percebeu meu olhar de leitora visual? Não viu o colecionador que a Porto Alegre moderna a ser mostrada descortinava-se ainda timidamente em apenas alguns traços quando o espaço urbano era visto no seu contexto maior? Daí o imperativo de lançar mão de dispositivos formais e visuais a fim de dar a ver o que se desejava. Se o contraste visual entre a cidade colonial e a cidade moderna é visível na alteração de sua feição arquitetônica em pontos como a Rua dos Andradas (fotografia 9), em outros, no entanto, as edificações de altura elevada são exceções em quarteirões nos quais predominavam prédios de poucos pavimentos (fotografia 7). Assim, a fim de salientar em todas suas nuances essas modificações materiais, o olhar seletivo do editor buscou aquela imagem que exacerbasse o contraste entre esses dois tempos. A escolha de imagem em repouso - ou seja, desprovida de qualquer elemento móvel - para a cena do final do século XIX corrobora ainda mais esta idéia, por utilizar meios formais que garantiriam a oposição com a ima- 
gem de dinamismo atribuído às cidades modernas. Posso, assim, mais uma vez notar que, do ponto de vista formal, nas imagens fotográficas de Porto Alegre Álbum foram utilizados vários procedimentos técnicos e estéticos em consonância com uma visualidade moderna, embora na cidade material à disposição dos fotógrafos convivessem elementos modernizantes ao lado de elementos remanescentes coloniais.

Experimento, novamente, a rapidez do olhar que havia mencionado. Não sem demora duas imagens me fazem desacelerar o passo. O motivo fotografado é o mesmo, a Avenida João Pessoa, porém uma vista é diurna e a outra é noturna (fotografias 11 e 12). Ambas estão aí com o objetivo de dar a ver as benesses da modernidade, aqui representada pela iluminação elétrica. De forma analítica, assim, o álbum dispõe duas imagens sobre o mesmo tema, como já o havia feito anteriormente com as imagens da Praça Marechal Deodoro. Neste, como naquele caso, quando mostra uma imagem inovadora em termos técnicos ou estéticos, oferece uma segunda vista do mesmo local utilizando procedimentos convencionais. Nas imagens da Praça Marechal Deodoro a imagem inovadora era uma vista aérea. Nessas imagens da Avenida João Pessoa, a imagem inovadora é uma vista noturna.

Porto Alegre Álbum apresenta duas vistas noturnas dispostas isoladamente, ambas de autoria do estúdio Azevedo e Dutra. A imagem da Avenida João

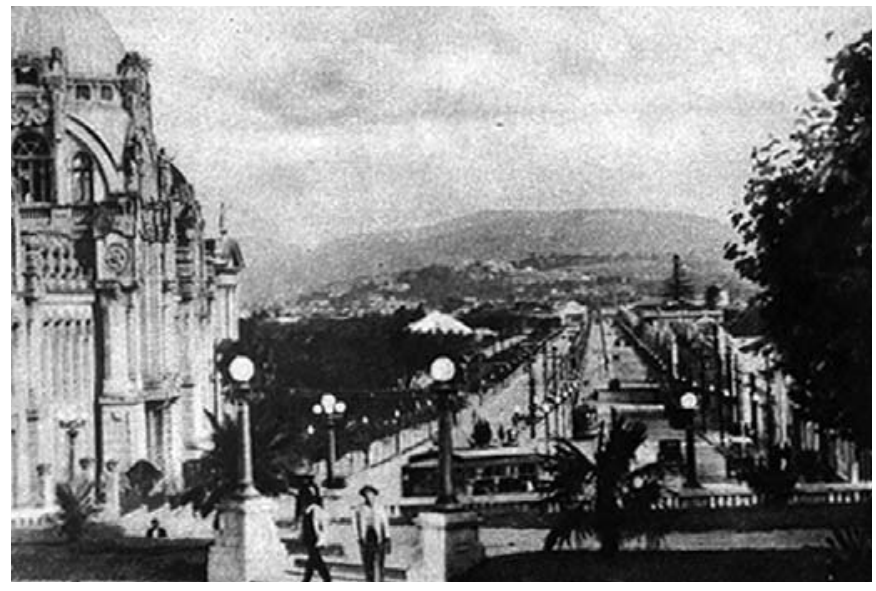

Fotografia 11 - Avenida João Pessoa - Comprimento 2.200 metros Largura 46 metros - Toda pavimentada de concreto armado. (legenda original) Fonte: CARVALHO, P. (Ed.) Porto Alegre álbum. Porto Alegre: A Noite, 1931. Acervo: MJJF/MCSHJC. 


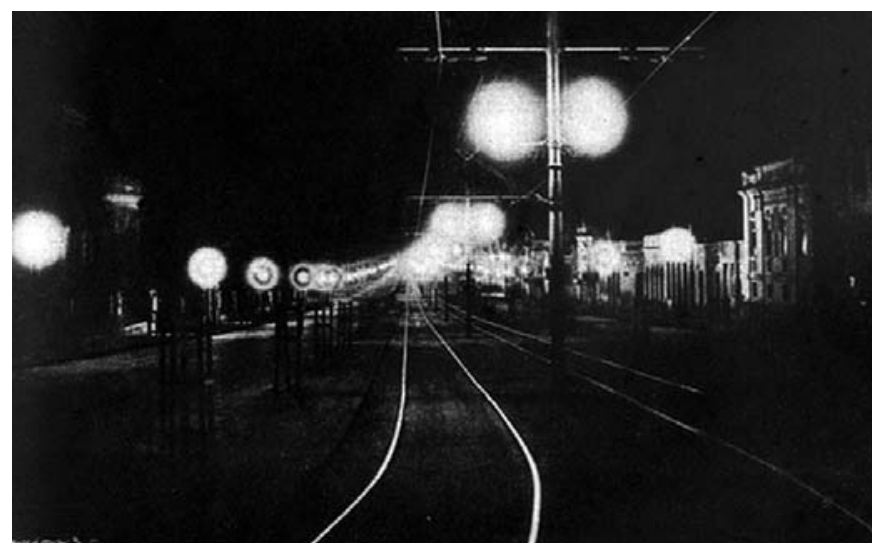

Fotografia 12 - Avenida João Pessoa, vista tomada pela madrugada. (legenda original) Fonte: CARVALHO, P. (Ed.) Porto Alegre álbum. Porto Alegre: A Noite, 1931. Acervo: MJJF/MCSHJC.

Pessoa é seguida por uma imagem também noturna da Rua dos Andradas (fotografia 13). Nas duas imagens as vias fotografadas apresentam características que dão uma feição misteriosa à cidade. Ambas apresentam alto contraste com a penumbra tomando grande proporção do quadro. Na escuridão das ruas podemos observar apenas os traços das edificações e postes de iluminação, calçadas, automóveis ou equipamentos urbanos. Praticamente toda a su-

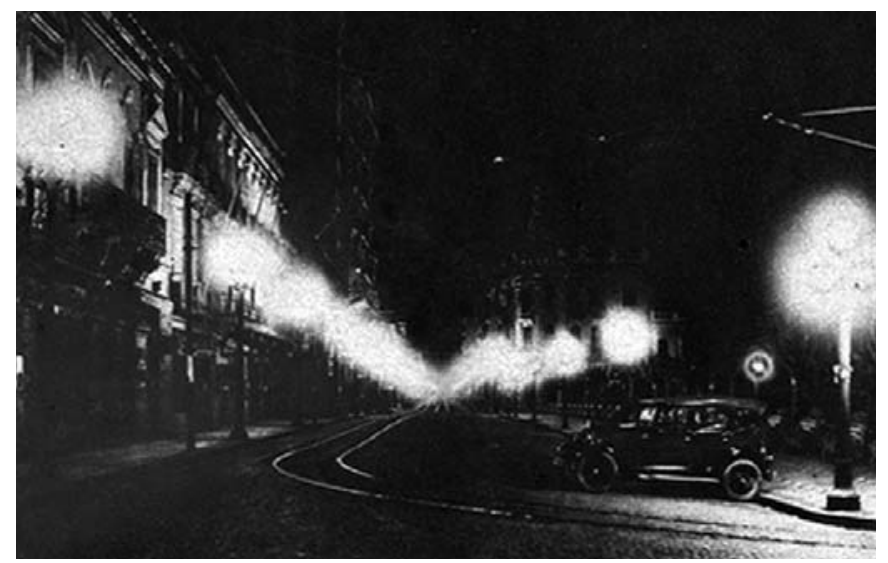

Fotografia 13 - Rua dos Andradas, vista tomada pela madrugada. (legenda original) Fonte: CARVALHO, P. (Ed.) Porto Alegre álbum. Porto Alegre: A Noite, 1931. Acervo: MJJF/MCSHJC. 
perfície da imagem se encontra na penumbra, na qual ganham grande destaque as lâmpadas dos postes de iluminação urbana como focos irradiadores de luz. Esses clarões assemelham-se a bolhas incandescentes suspensas sobre as avenidas, dando à cidade uma atmosfera mágica e encantadora. Os trilhos metálicos dos bondes elétricos refletem essa luz proveniente dos postes, o que configura o desenho de suas linhas curvas que acompanham o traçado das vias. Esses contornos aproximam-se daqueles presentes em imagens, nas quais se utilizavam os faróis dos automóveis para desenhar e construir composições quase abstratas, numa representação cênica afinada com os padrões de visualidade fotográfica das grandes metrópoles. Ainda seriam necessárias algumas décadas para que os fotógrafos da Escola Paulista ${ }^{34}$ realizassem imagens utilizando esses artifícios.

No entanto, as vistas noturnas presentes no álbum analisado são de grande relevância na construção de uma nova visualidade de Porto Alegre. Apenas alguns anos antes os porto-alegrenses haviam conhecido as primeiras imagens fotográficas noturnas feitas na cidade, sobretudo os magnésios de casamento. $\mathrm{O}$ autor da façanha de experimentar a perigosa explosão de pó de magnésio para obtenção de imagens em ambientes com pouca ou nenhuma luminosidade fora o fotógrafo Olavo Dutra. É por essa época, assim, que pela primeira vez é possibilitado visualizar em imagem a cidade à noite, não sendo também por acaso que o estúdio de Olavo Dutra assine justamente as fotografias noturnas de Porto Alegre Álbum. Ao que tudo indica, esse profissional deveria ser o mais habilitado na nova invenção ou quem sabe até mesmo o único na cidade a realizar vistas noturnas, pelo menos enquanto o engenho era novidade.

Aquele estúdio, dessa forma, parecia ter como objeto de suas experimentações a elaboração de vistas urbanas noturnas. Essas duas imagens foram realizadas sem o recurso do flash, graças a uma longa exposição, conseguida com a utilização do tripé. O fotógrafo procedendo dessa maneira obteve sucesso em dar maior profundidade à cena urbana fotografada. As bolhas incandescentes que surgem na imagem são justamente criadas pela longa exposição, quando o diafragma permanece aberto por alguns minutos. Na realização dessas vistas noturnas, o tempo de exposição variava. Em imagens com menor tempo de exposição, poderiam ser captadas até mesmo imagens de pessoas em movimento, como se percebe em outra vista noturna presente no mesmo álbum.

O efeito de suspensão de bolhas de luz sobre a cidade enegrecida dá às imagens da Avenida João pessoa e da Rua dos Andradas uma grande beleza 
plástica que ultrapassa a habilidade necessária para realizar vistas da cidade à noite. Mais que dar a ver um elemento que colocava Porto Alegre no rol das cidades modernas, a iluminação elétrica, as imagens noturnas de Olavo Dutra deram glamour ao espaço urbano, envolvendo a cidade de pedra em uma aura de sonho e fantasia. Melhor não faria uma imagem fotográfica no sentido de propiciar ao leitor visual o veículo que o transportasse para uma atmosfera de encantamento e irrealidade. As imagens de Olavo Dutra são, assim, porta-vozes do devaneio da burguesia porto-alegrense ao imaginar-se vivenciando a modernidade, por oferecer os elementos visuais que tornaram esse sonho bastante próximo do seu cotidiano.

Rua dos Andradas, vista tomada pela madrugada (fotografia 13) foi escolhida para encerrar a seqüência de imagens apresentadas de forma isolada desde o início da publicação. Essa vista noturna dá uma idéia de repouso à cidade, que adormece após a labuta diurna de grandes obras.

As imagens seguintes são apresentadas em conjuntos de duas, de três e de quatro vistas, seqüência interrompida apenas em três momentos por imagens isoladas. Os agrupamentos de duas imagens são em maior número, conforme mostrei anteriormente. A diagramação dessas páginas com agrupamentos pode apresentar as imagens fotográficas na diagonal ou em composições de formatos horizontais e verticais, de acordo com o motivo fotografado.

Vários desses conjuntos de imagens permitem estabelecer uma relação entre os temas fotografados (edifícios, áreas verdes, escolas, quartéis). No mesmo sentido de agrupar motivos relacionados que estão em foco, são apresentados em conjuntos variando de duas a cinco imagens sete Grupos de residências particulares (fotografias 16 a 20). Outros conjuntos compõem-se de imagens de idêntica temática, porém, apresentada sob pontos de vista diferenciados, encerrando uma perspectiva analítica do assunto ali em foco. Há as vistas externas e internas do motivo fotografado, como é o caso das imagens de bondes e da Galeria Chaves. Há uma vista mais ampla associada a outra de detalhe do mesmo tema: duas imagens da Rua Independência; duas imagens das obras de construção da Avenida Borges de Medeiros; uma vista aérea e outra em detalhe da Praça Parobé; vistas das estradas de concreto, e duas imagens agrupadas do Guaíba, que encerram o álbum.

Dentre esses últimos conjuntos, nota-se o destaque conferido à temática Hidráulica, motivo com maior número de imagens apresentado em conjunto na totalidade da publicação. São sete imagens ao todo, sendo seis correspondentes a vistas externas de edificações, tanques e jardins, e uma vista interna. A temática Cais do Porto é representada em quatro imagens, mas diferente- 


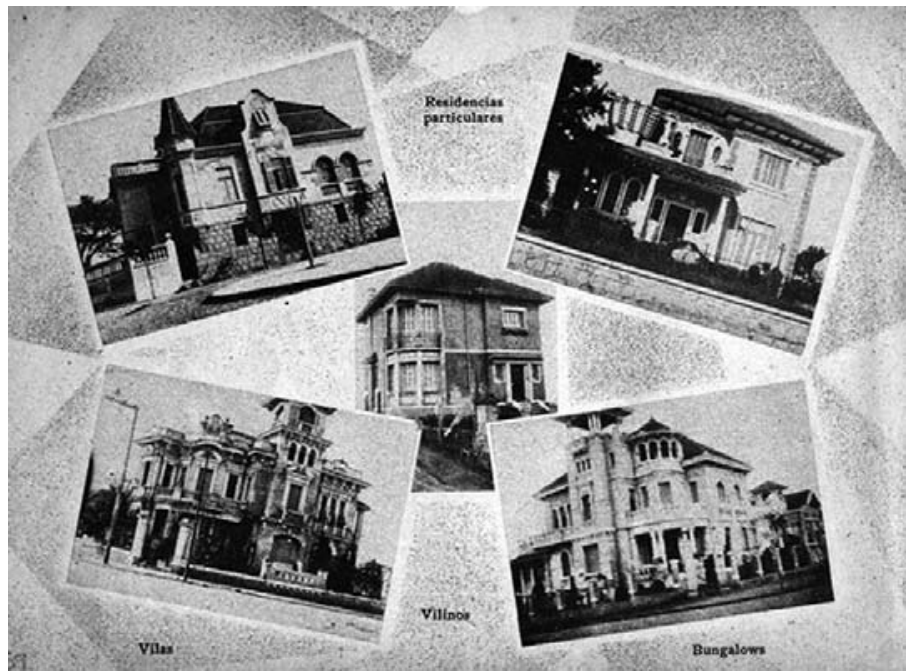

Fotografia 17 a 20 - Residências particulares. Vilas, Vilinos, Bungalows (legenda original). Fonte: CARVALHO, P. (Ed.) Porto Alegre álbum. Porto Alegre: A Noite, 1931. Acervo: MJJF/MCSHJC.

mente dos conjuntos anteriormente mencionados, neste caso, uma imagem isolada está associada a outras três imagens agrupadas em página ao lado, mostrando pontos de vista diferenciados do motivo focado.

Ainda são vistos conjuntos, compostos cada um por duas imagens não apresentando relação entre si no que se refere ao motivo fotografado.

A seqüência de conjuntos de imagens agrupadas é interrompida, como já mencionei, apenas em três momentos por imagens fotográficas isoladas que rompem com a visualidade monótona de imagens de dimensão reduzida dispostas, em sua grande maioria, na transversal. A primeira imagem isolada que rompe, assim, com essa diagramação já foi analisada anteriormente e compreende uma vista aérea da ponta da península, impressa em papel de dimensão e qualidade superiores ao restante do álbum. Logo após essa imagem, é feita uma homenagem ao ex-intendente Otavio Rocha, através da associação do seu retrato emoldurado em formato oval com uma vista do entardecer sobre o Guaíba. Essa reverência póstuma ao ex-intendente é justificada, conforme informa a legenda, por ter sido ele o "benemérito iniciador das obras de remodelação de Porto Alegre. — Falecido em 27 de fevereiro de 1928”. ${ }^{35}$

Segue-se a essa homenagem a seqüência de conjuntos de imagens agrupadas da temática Hidráulica, já mencionada, novamente rompida com uma 
imagem isolada da obra em desenvolvimento da Avenida Osvaldo Aranha. Retoma-se a seqüência perdida que, mais uma vez — a última - é rompida por uma imagem isolada do Cais do Porto.

O agrupamento de imagens não dá a ver com o mesmo impacto os motivos fotografados se comparado com a disposição de imagens isoladas. $\mathrm{Na}$ primeira seqüência de imagens isoladas o 'olhar detido', conforme caracterizei há pouco, detém-se vagarosamente sobre cada imagem fotográfica, examinando seus detalhes, visitando e revisitando diminutos lugares. Nesse sentido, são essas as imagens que marcam a visualidade do álbum e, por conseguinte, da cidade. A tendência ao observar as imagens agrupadas é acelerar o olhar, fazendo que ele vagueie entre uma vista e outra. Perde-se nos detalhes visuais, mas ganha-se na busca de relações, associações, contrastes, complementações e comparações entre as imagens oferecidas.

O conjunto de imagens referentes às temáticas Cais do Porto e Hidráulica contribui nesse sentido. No primeiro caso, a vista isolada do cais tomada a partir de um barco, cuja proa é deixada à mostra para indicar a localização do olhar fotográfico, descortina uma paisagem ampla na qual as águas do Guaíba e o horizonte ao fundo ocupam dois terços do quadro fotográfico. Ao lado, o conjunto de três imagens decompõe o tema principal, apresentando aspectos dos navios ancorados, dos guindastes, dos passageiros que aguardam o embarque. No mesmo sentido, as imagens da Hidráulica apresentam vários pontos de vista do tema principal, tomadas amplas que valorizam uma das obras urbanas de maior envergadura no escopo da remodelação implementada pelos positivistas na Intendência.

Merecem ainda menção as imagens das obras de abertura da Avenida Borges de Medeiros (fotografias 14 e 15), por transformar em objeto de exibição de um álbum fotográfico um tema inusitado. Não é uma vista da cidade com seus elementos aformoseadores, como jardins, praças e obras de arte, que se descortina ao leitor visual, mas o próprio processo do fazer-se da cidade. Escombros, andaimes, estruturas, alicerces, escoramentos são oferecidos ao olhar tais como vísceras do corpo da cidade, exposto em mais uma cirurgia urbana e elevado à contemplação estética através da imagem fotográfica. Não foi de modo algum o fato de fotografar o tema das obras urbanas que me poderia ter causado certo espanto. A função documental dada à fotografia desde os seus primórdios incluiu o registro das obras viárias. O inusitado aqui me pareceu estar situado na inclusão da imagem dessas obras no álbum fotográfico. E que todos esses elementos desprovidos de beleza, se comparados com as demais imagens da cidade presentes em Porto Alegre Álbum, estivessem aqui alçadas também à contemplação estética urbana. 


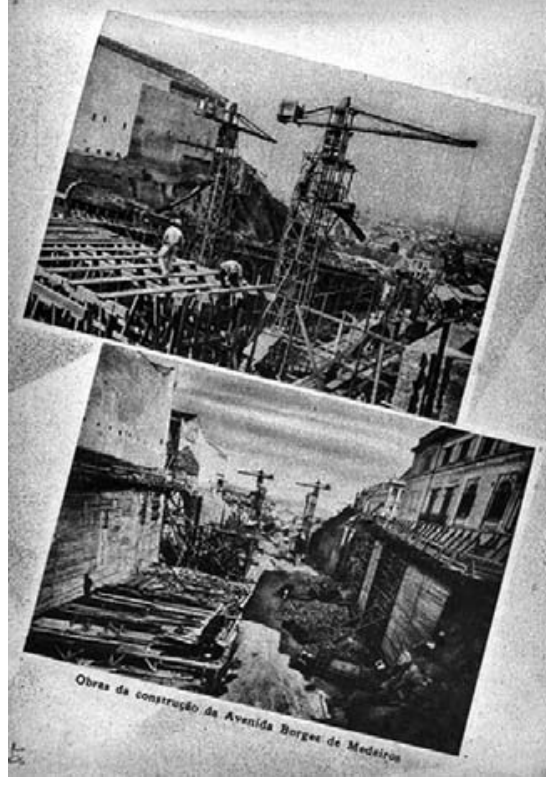

Fotografia 14 e 15 - Obras da Construção da Avenida Borges de Medeiros. (legenda original) Fonte: CARVALHO, P. (Ed.) Porto Alegre álbum. Porto Alegre: A Noite, 1931. Acervo: MJJF/MCSHJC.

O paradoxo, no entanto, esboroa-se no momento em que percebo que essas imagens de obras viárias, que expõem o corpo da cidade de forma tão 'desrespeitosa', exibem o trabalho sobre o corpo de uma cidade revolvida por pás e picaretas e de cujo processo de transformação deverá surgir uma nova cidade de fisionomia almejada pelos produtores da edição.

As imagens fotográficas das obras urbanas, assim, tendem a fazer notar a mudança, mola propulsora da modernização do espaço urbano das cidades. Se Porto Alegre não se apresenta ainda de forma tão convincente nas imagens fotográficas como moderna, higiênica e bela, as imagens de seu processo de transformação não deixam dúvidas quanto ao lugar a que esta deseja chegar. A grandiosidade da obra mostrada em imagem fotográfica deixa, assim, às claras o ideal de cidade almejado.

A imagem fotográfica das obras urbanas, porém, incorpora esse motivo na visualidade da cidade moderna. As obras, dessa forma, deixam o âmbito material assumindo uma dimensão visual ao serem veiculadas em cartões postais ou álbuns fotográficos, contribuindo na propagação de um imaginário do moderno ligado às alterações do espaço urbano.

A presença das imagens das obras da Avenida Borges de Medeiros em Porto Alegre Álbum tende a mostrar a complexidade associada a tal ação, para a cidade. Das obras de remodelação iniciadas na gestão de Otavio Rocha, é a 
única que não está concluída quando da edição do álbum fotográfico, em 1931. Pela sua grandiosidade e importância, no entanto, mereceu ter a imagem de suas obras ao lado de outros aspectos da cidade ali mostrados.

Detive-me nas imagens dessas obras, pensando que a imagem do Viaduto e da Avenida Borges de Medeiros somente seria amplamente divulgada na composição de uma visualidade da cidade moderna após sua conclusão, quando inseridos no âmbito de uma imagem de cidade um pouco diferenciada da visualidade criada pelo álbum de $1931 .{ }^{36}$ As imagens das obras, no entanto, não deixam de compor essa narrativa do início dos anos 30, indicando que as transformações não lograriam término e que a mudança, principalmente no cenário urbano, era uma tônica da modernidade que chegava à cidade.

Essa acepção afina-se com a idéia de um fio condutor da narrativa do álbum que é marcada por um 'olhar detido' sobre a cidade. Retomando as primeiras imagens do conjunto - agora que a coleção está fechada e a última página foi visualizada — esse viés parece se confirmar, principalmente na primeira seqüência de imagens isoladas. Nelas parecem conviver duas imagens de cidade: uma de traços ainda remanescentes da Porto Alegre colonial, outra que se esforça por acentuar seus aspectos vinculados à modernidade. Nelas pode-se perceber um diálogo conflituoso entre o visível e o invisível, entre o que se desejou dar a ver e o que se teve a intenção de excluir da cena fotografada.

Continuando na urdidura desse enredo, as duas imagens da Rua dos Andradas marcam, sem dúvida, uma composição destacada no conjunto do álbum, graças à série de aspectos e signos que comportam. O contraste entre dois tempos dá a ver a transformação operada no espaço urbano, valoriza a imagem de cidade moderna e cria uma determinada memória da cidade colonial, alargando o distanciamento entre uma cidade sonhada, que se dá a ver em imagem, e outra, que perdura sub-repticiamente, deixando visível o que não deveria ser mostrado.

\section{NOTAS}

${ }^{1}$ Este texto é parte da tese de doutorado da autora, intitulada Cidade fotografada: memória e esquecimento nos álbuns fotográficos de Porto Alegre — décadas 1920 e 1930. Doutorado (História) - Programa de Pós-Graduação em História, Instituto de Filosofia e Ciências Humanas, Universidade Federal do Rio Grande do Sul, Porto Alegre, 2005.

${ }^{2}$ LE ROUX, Philippe. Les vies parallèles des photographes. La recherche photographique, Paris, n.10, p.27-34, juin 1991. p.27.

${ }^{3}$ SCHAER, Roland. L'Invention des musées. Paris: Gallimard; Reunion des Musées Nationaux, 1993. 
${ }^{4}$ POMIAN, Krzysztof. Colecção. In: Enciclopédia Einaudi. v.1 (Memória-História). Lisboa: Imprensa Nacional/Casa da Moeda, 1984. p.51-86. p.77.

${ }^{5}$ Ibidem, 1984, p.71.

${ }^{6}$ SONTAG, Susan. Ensaios sobre fotografia. São Paulo: Companhia das Letras, 2004. p.13.

${ }^{7}$ Ibidem.

${ }^{8}$ LE ROUX, Philippe. Les vies parallèles des photographes, cit., p.28.

${ }^{9}$ PESAVENTO, Sandra J. Em busca de uma outra história: imaginando o imaginário. $R e$ vista Brasileira de História, São Paulo, v.15, n.29, p.9-27, 1995.

${ }^{10}$ AUMONT, Jacques. A imagem. Campinas: Papirus, 1993. p.245.

${ }^{11}$ BENJAMIN, Walter. O narrador: considerações sobre a obra de Nikolai Leskov. In: Magia e técnica, arte e política: ensaios sobre literatura e história da cultura. 3.ed. São Paulo: Brasiliense, 1987b. p.197-221. (Obras escolhidas, v.1, p.201).

${ }^{12}$ LE GOFF, Jacques. História e memória. Campinas: Ed. Unicamp, 1994. p.429.

${ }^{13}$ Benjamin, 1987b, p.203.

${ }^{14}$ Ibidem.

${ }^{15}$ FLUSSER, Vilém. Filosofia da caixa preta: ensaios para uma futura filosofia da fotografia. Rio de Janeiro: Relume-Dumará, 2002. p.14.

${ }^{16}$ Ibidem, p.8.

${ }^{17}$ Foi inspiradora para essa abordagem do flâneur a leitura de GONÇALVES, José Reginaldo Santos. Os museus e a cidade. In: ABREU, Regina; CHAGAS, Mário (Org.) Memória e patrimônio: ensaios contemporâneos. Rio de Janeiro: DP\&A, 2003. p.175-89.

${ }^{18}$ BENJAMIN, Walter. Charles Baudelaire: um lírico no auge do capitalismo. São Paulo: Brasiliense, 1989. (Obras escolhidas, v.3, p.122).

${ }^{19}$ CARVAlHO, Pedro (Ed.) Porto Alegre álbum. Porto Alegre: A Noite, 1931. Não paginado. ${ }^{20}$ PESAVENTO, Sandra J. O imaginário da cidade: visões literárias do urbano, Paris, Rio de Janeiro, Porto Alegre. Porto Alegre: Ed. Universidade/UFRGS, 1999. p.350.

${ }^{21}$ KOSSOY, Boris. Realidades e ficções na trama fotográfica. 3.ed. São Paulo: Ateliê Editorial, 2002. p.47.

${ }^{22}$ CIDADE, Daniela Mendes. A cidade revelada: a fotografia como prática da assimilação da arquitetura. Dissertação (Mestrado em Teoria, História e Crítica da Arquitetura) Programa de Pós-Graduação em Arquitetura, Faculdade de Arquitetura, Universidade Federal do Rio Grande do Sul, Porto Alegre, 2002. p.26.

${ }^{23}$ PHILLIPS, Christopher. La photographie des années vingt: l'exploration d'un nouvel espace urbain. La recherche photographique, Paris, n.17, p.30-7, automne, 1994. p.35.

${ }^{24}$ Deve-se considerar que Porto Alegre foi o berço da aviação comercial brasileira com a fundação da primeira companhia brasileira de transportes aéreos: Empresa de Viação Aérea Rio Grandense (Varig). Cf. SPALDING, Walter (Comp.) Porto Alegre: monografia edi- 
tada sob os auspícios da Prefeitura Municipal. São Paulo: Limitada, 1953.p.88-9; TEIXEIRA, Luiz T. Por que Porto Alegre é alegre, tchê? Porto Alegre: Feplam, 1988. p.136.

${ }^{25}$ PHILLIPS (1994) mostra como esses e outros artistas interpretaram conceitos de velocidade, objetividade e montagem para representar a metrópole nos anos 20.

${ }^{26}$ Sobre a relação fotografia-arquitetura ver CARVALHO, Maria Cristina W. de; WOLFF, Silvia Ferreira Santos. Arquitetura e fotografia no século XIX. In: FABRIS, Annateresa (Org.) Fotografia: usos e funções no séc. XIX. São Paulo: Edusp, 1991. p.131-72.

${ }^{27}$ CIDADE, 2002, cit., p.57.

${ }^{28}$ POE, Edgar A. O homem da multidão. In: Histórias extraordinárias. São Paulo: Cultrix, 1968. p.235-43.

${ }^{29}$ PESAVENTO, Sandra J. O espetáculo da rua. Porto Alegre: Ed. Universidade/UFRGS/Prefeitura Municipal, 1992.

${ }^{30}$ A partir dos anos 20, ficou conhecido como Largo dos Medeiros a área situada na esquina da Rua General Câmara com Rua dos Andradas, em razão do nome dos proprietários da Confeitaria Central, um dos principais estabelecimentos ali localizados. O Largo dos Medeiros, nas primeiras décadas do século XX, constituiu importantesponto de sociabilidade das camadas altas e médias da sociedade porto-alegrense, reunindo confeitaria, livraria e café.

${ }^{31}$ SAINT-HILAIRE, Auguste. Viagem ao Rio Grande do Sul. (Trad. Adroaldo Mesquita da Costa). Porto Alegre: Erus, 1987. p.43.

${ }^{32}$ FLUSSER, Vilém. Filosofia da caixa preta: ensaios para uma futura filosofia da fotografia, cit., p.31.

${ }^{33}$ KOSSOY, Boris. Realidades e ficções na trama fotográfica, cit., p.140.

${ }^{34}$ Sobre a fotografia modernista brasileira ver COSTA, Helouise; RODRIGUES, Renato. A fotografia moderna no Brasil. São Paulo: Cosac Naify, 2004.

${ }^{35}$ CARVAlHO, Pedro (Ed.) Porto Alegre álbum. Porto Alegre: A Noite, 1931.

${ }^{36}$ Refiro-me às imagens fotográficas da Avenida Borges de Medeiros realizadas após a década de 1940, as quais apresentam quarteirões uniformes compostos por edificações de dezenas de pavimentos. 